\title{
A Revista Crítica de Ciências Sociais e o Feminismo (1978-2017)
}

Revista Crítica de Ciências Sociais and Feminism (1978 2017)

La Revista Crítica de Ciências Sociais et le féminisme (1978 2017)

\section{Adriana Bebiano e Maria Irene Ramalho}

\section{OpenEdition}

\section{Journals}

Edição electrónica

URL: http://journals.openedition.org/rccs/7709

DOI: $10.4000 /$ rccs. 7709

ISSN: 2182-7435

\section{Editora}

Centro de Estudos Sociais da Universidade de Coimbra

Edição impressa

Data de publição: 7 Novembro 2018

Paginação: $71-114$

ISSN: 0254-1106

\section{Refêrencia eletrónica}

Adriana Bebiano e Maria Irene Ramalho, «A Revista Crítica de Ciências Sociais e o Feminismo

(1978-2017) », Revista Crítica de Ciências Sociais [Online], Número especial | 2018, colocado online no dia 05 novembro 2018, criado a 19 abril 2019. URL : http://journals.openedition.org/rccs/7709 ; DOI $10.4000 /$ rccs. 7709 


\section{ADRIANA BEBIANO, MARIA IRENE RAMALHO}

\section{A Revista Crítica de Ciências Sociais e o Feminismo (1978-2017)*}

O objectivo deste artigo é reflectir criticamente sobre os trabalhos publicados na Revista Crítica de Ciências Sociais (RCCS), desde a sua fundação até aos dias de hoje, concretamente sobre aqueles que se relacionam com temáticas feministas. Deste olhar crítico, em articulação com as teorias feministas emergentes das últimas décadas, resultará certamente uma imagem renovada que de si tem a RCCS. E de igual modo o Centro de Estudos Sociais da Universidade de Coimbra.

Palavras-chave: cidadania; epistemologia crítica; feminismo; Revista Crítica de Ciências Sociais.

\section{Introdução}

Nos 40 anos do Centro de Estudos Sociais (CES) da Universidade de Coimbra, coube-nos o desafio de reflectir sobre a presença do Feminismo na Revista Crítica de Ciências Sociais (RCCS) ao longo deste período. Por Feminismo, entendemos a epistemologia crítica que rejeita a hierarquização sexual, seja ela explícita ou meramente implícita, e denuncia o reconhecimento desigual e a desigual distribuição por razão do sexo (ou de qualquer outra diferença). Os conceitos de diferença e igualdade são cruciais no nosso pensamento. Temos presente uma formulação de Boaventura de Sousa Santos, publicada pela primeira vez nas páginas da RCCS: "as pessoas e os grupos sociais têm o direito a ser iguais quando a diferença os inferioriza, e o direito a ser diferentes quando a igualdade os descaracteriza" (Santos, 1997: 30). Consideramos pertinentes para o nosso artigo áreas do saber presentes na RCCS que a si próprias se designam como Estudos Feministas, Estudos sobre as Mulheres, Estudos de Género, Estudos Queer e Estudos sobre a Sexualidade. Em qualquer destas áreas, encontrámos na RCCS artigos que se posicionam, explícita ou implicitamente, de acordo com as

\footnotetext{
Por vontade das autoras, este artigo não segue as regras do Acordo Ortográfico de 1990.
} 
chamadas "vagas" do feminismo: ${ }^{1}$ a primeira (de finais do século XIX até à década de 1960), focada no sufrágio e na igualdade (social, económica, política); a segunda (décadas de 1960-1970), centrada na denúncia do patriarcado e na luta pelos direitos sociais e sexuais das mulheres; a terceira (décadas de 1980-), a reclamar o reconhecimento da diferença e o respeito pela identidade, diversidade e cultura individuais; tem-se falado já de uma quarta vaga, empenhada em derrotar completamente a nossa milenar cultura misógina e a violenta predação sexual que dela resulta. No seguimento da revelação do já-sabido na recente explosão dos movimentos \#MeToo e Time's Up, Prudence Crowther imagina uma divertida confissão de Zeus, que finalmente parece descobrir-se responsável. Os versos de uma canção dos Beatles (Yesterday) a fechar o artigo insinuam, porém, que é oca a contrição do divino predador ("I am not half the man I used to be/There is a shadow hanging over me" [Já não sou nada do homem que fui/Paira sobre mim uma sombra]). ${ }^{2}$

$\mathrm{Na}$ nossa análise dos artigos de pendor feminista publicados na RCCS sobre variados temas, julgámos detectar a predominância de duas posições teóricas, por vezes articuladas entre si, que costumam identificar-se pelos conceitos de redistribuição (primeira e segunda vagas) e reconbecimento (terceira vaga). O reconhecimento, que se articula com as políticas de identidade e o chamado cultural turn, vai ter projecção na RCCS a partir de certa altura, nomeadamente no âmbito dos Estudos Queer e das temáticas LGBTQI (Lésbicas, Gays, Bissexuais, Transgénero, Queer e Intersexo). Por outro lado, verificámos que a maior parte dos artigos procuram colocar-se, consciente ou inconscientemente, e com preocupações de inclusividade ou não, do ponto de vista das mulheres. Ou seja, o feminismo que percorre a RCCS nestes 40 anos não foi alheio, se bem que por vezes avant la lettre, à "teoria do ponto de vista" (standpoint theory), formulada por Sandra Harding no início dos anos 1990. ${ }^{3}$

A questão da redistribuição/reconbecimento resulta muito clara do debate entre Nancy Fraser e Judith Butler nos finais dos anos 90 do século passado. Na sequência da publicação de Justice Interruptus, de Nancy Fraser, e reagindo sobretudo ao seu primeiro capítulo, Butler acusa Fraser de situar a discussão apenas dentro da heteronormatividade e de desvalorizar como "meramente culturais" - e não políticas e económicas -

\footnotetext{
${ }^{1}$ Usamos aqui o conceito redutor de "vaga" por uma questão de comodidade.

2 Crowther, 2018; Yesterday (Beatles).

3 Cf. Harding, 1991, 2004. Muito útil a introdução da organizadora: "Standpoint Theory as a Site of Political, Philosophic, and Scientific Debate" (2004: 1-15).
} 
as lutas pelo reconhecimento das diferentes identidades sexuais, as quais, defende Butler, ameaçam a ordem capitalista, uma ordem, argumenta a filósofa, que sabe muito bem tirar partido da heteronormatividade. ${ }^{4}$ $\mathrm{Na}$ sua resposta, que apareceu no mesmo número da revista em que foi publicada a crítica de Butler, Fraser reitera a sua crítica marxista do capitalismo e a sua demanda socialista pela redistribuição e pela justiça social, ao mesmo tempo que reconhece a importância das políticas de identidade valorizadas por Butler. Em nosso entender, o feminismo e a justiça social lucrarão com a articulação entre ambas as teorias. As diferentes posições das duas autoras podem ver-se consolidadas em Antigone's Claim, de Butler (2000), e "Social Justice in the Age of Identity Politics", de Fraser (2003). ${ }^{5}$

O Editorial do número 1 da RCCS, assinado por Boaventura de Sousa Santos (Julho 1978) e claramente de inspiração marxista, por via sobretudo da Escola de Frankfurt, deixava bem claro que o rigor científico reclamado para a Revista, que se queria inovadora, inclusiva e crítica, andaria sempre aliado ao propósito de contribuir para uma sociedade mais igualitária, mais justa e mais solidária.

Uma frase, aliás repetida em números seguintes, sobressai nesse primeiro Editorial: "A crítica só vê quando se vê" (p. 7). Da perspectiva da temática que aqui nos ocupa, salta à vista o que a crítica das Ciências Sociais ainda não estava a ver: três artigos assinados por três investigadores do sexo masculino, três recensões assinadas por outros três investigadores do sexo masculino, três notícias igualmente assinadas por outros três investigadores do sexo masculino - sendo que um deles assina também um dos artigos. Nenhum dos temas abordados em todos estes textos tem qualquer referência à situação, ou sequer existência, das mulheres na sociedade, salvo uma breve alusão de passagem a movimentos "marginais" de libertação das mulheres numa notícia dando conta do V Congresso do Grupo Europeu para o Estudo do Desvio e do Controlo Social, que decorreu em Barcelona em 1977. O contexto histórico, social e académico da produção do número explica este pormenor circunstancial, em que não vamos deter-nos aqui. Em virtude desse mesmo contexto, a participação de mulheres investigadoras na RCCS foi surgindo lentamente. E as perspectivas feministas ainda mais lentamente. $\mathrm{O}$ número 2 inclui um artigo

\footnotetext{
${ }^{4}$ Curiosamente, é Nancy Fraser quem, em artigo de opinião publicado em The Guardian, alerta para a necessidade de denunciar e rebater o aproveitamento neoliberal do feminismo da segunda vaga. Cf. Fraser, 2013.

5 Ver também Fraser, 1997a: 11-39, 1997b: 279-289, 2003: 7-109; Butler, 1997: 265-267, 2000.
} 
de uma psicóloga (Brigitte Detry Cardoso e Cunha, 1978), que assina com dois alunos seus - em si, um gesto inovador e sem precedentes na academia portuguesa de então e ainda hoje não muito comum em qualquer lado no âmbito das Humanidades - e o número 3 contém uma recensão assinada por uma linguista (Ana Cristina Macário Lopes, 1979). Foi preciso chegar ao número duplo 4/5 (Outubro 1980) para se ler trabalho original de mulheres investigadoras (Graça Abranches, Isabel Caldeira, Maria Irene Ramalho) e apreciar preocupações a que poderemos já chamar feministas.

Desde então, a presença na RCCS do pensamento feminista, nas suas várias vertentes e no âmbito das mais variadas disciplinas, tem sido uma constante, quer explícita quer implícita, seja em artigos de fundo ou simples recensões críticas. Curiosamente, o número triplo $(18 / 19 / 20,1986)$ que resultou do grande congresso comemorativo dos 10 anos da Revolução dos Cravos, realizado em 1984, contém apenas um artigo que reflecte sobre o estatuto das mulheres. Assinado pela linguista da Faculdade de Letras da Universidade de Lisboa, Isabel Hub Faria, e por Maria José Grosso e Rosa Lopes (1986), duas alunas suas de mestrado, "Dez anos de auto-referência. Que transformação para a orientação do significado de mulher na Assembleia da República?" verifica que os dez anos de Revolução não trouxeram alterações nas dinâmicas de reconhecimento e poder entre homens e mulheres. Em 1984, mesmo na Assembleia da República, homens e mulheres continuam a pensar-se, agir, inter-agir e falar, por um lado, como "o sexo-que-é", por outro, como "o sexo-que-não-é”. Ou, como diria Beauvoir, "o segundo sexo" (cf. Ramalho, 2001b: 525-555). Dez anos mais tarde, a propósito da publicação do best-seller de Deborah Tannen (1990) e da polémica que suscitou na altura, a sociolinguista da Faculdade de Letras da Universidade de Coimbra (FLUC), Clara Keating (1994), haveria de reflectir criticamente sobre as dinâmicas de poder que determinam a construção da diferença sexual na linguagem, em "A construção da polémica da hegemonia e da diferença nos estudos sobre linguagem e diferença sexual (A propósito de You Just Don't Understand, de Deborah Tannen)".

\section{Literatura e Feminismo}

O Editorial do primeiro número temático da RCCS (4/5, Outubro 1980) sublinha as preocupações interdisciplinares da Revista ao confiar a organização de um número sobre "Literatura em sociedade" a estudiosos de literatura e cultura do Grupo de Estudos Anglo-Americanos da FLUC. Pela mão das Humanidades, e da Literatura em particular, o CES abria-se 
a temáticas relacionadas com a arte, a literatura e a cultura, sobressaindo neste número artigos sobre o ensaio teórico, a ficção científica, o romance policial, a literatura afro-americana, a literatura fantástica, o conto tradicional, a narrativa de vida operária, a cultura de massas. Alguns dos textos revelam-se atentos a quem tem, ou não, acesso privilegiado à palavra por razão de classe, raça ou sexo, mas o texto que verdadeiramente inaugura uma perspectiva feminista na RCCS e no CES é assinado por Graça Abranches, especialista de Literatura Inglesa. ${ }^{6}$

$\mathrm{Na}$ sua análise do clássico ensaio feminista de Virginia Woolf em "Re-lendo A Room of One's Own. Onde se conta de mudas que ouvem, surdos que falam e mudas que aprenderam a falar", Graça Abranches (1980) combina pressupostos de teoria literária e crítica textual com uma apurada reflexão linguística, sociológica e política. Para além da questão linguística e literária acerca de uma língua que as mulheres já não tenham de roubar ao discurso patriarcal dominante, antes a conquistem e reinventem por direito próprio, o ensaio sublinha o anti-elitismo e a ironia com que Virginia Woolf desconfia da objectividade do discurso académico ortodoxo (ou "academês") sobre as mulheres, ao mesmo tempo que denuncia a segregação, discriminação e opressão específicas das mulheres em sociedade no capitalismo. Ideia central no ensaio de Woolf sobre a secundarização das mulheres na sociedade é a sua falta de independência económica resultante da desigual distribuição. A figura do andrógino invocada por Woolf no final do seu ensaio entende-a Graça Abranches como metáfora de uma sociedade isenta da divisão sexual do trabalho (p. 152). Nós hoje inclinamo-nos mais a entendê-la como uma forma de rejeitar a hierarquização da diferença (sexual), como sugere aliás o poema de Adrienne Rich, "The Stranger", que empresta ao artigo de Abranches uma das epígrafes (cf. Ramalho Santos, 2013).

Outra das epígrafes é uma citação da socióloga inglesa, marxista e feminista, Sheila Rowbotham (1973: 117), a sublinhar a importância de, ao mesmo tempo, distinguir e fazer convergir sexo e classe nas lutas de um e de outra contra a opressão. Que a luta contra o capitalismo deve convergir com a luta contra o patriarcado é o grande postulado de toda a obra de Sheila Rowbotham, que Graça Abranches muito admira. O seu trabalho seguinte na RCCS (Abranches, 1981) é justamente uma recensão crítica muito favorável de uma obra a apontar a necessidade da convergência,

${ }^{6}$ Graça Abranches foi quem primeiro introduziu cadeiras de Estudos Feministas na Universidade de Coimbra, mais precisamente nos cursos de licenciatura em Línguas e Literaturas Modernas da Faculdade de Letras (cf. Abranches, 1998). 
ou interseccionalidade, das lutas - Beyond the Fragments. Feminism and the Making of Socialism (1979), assinada por Sheila Rowbotham, Lynne Segal e Hilary Wainwright. ${ }^{7}$

O feminismo entrou, assim, na RCCS pela mão da Literatura, e, sem surpresa, de mãos dadas com a epistemologia crítica que presidira à sua criação. Veja-se como neste número $4 / 5$ ele surge como um dos modos de problematizar o próprio conceito de literatura e de renovar cientificamente o seu estudo, questionando, por exemplo, a distinção entre alta e baixa cultura - como jocosamente faz o Editorial do número 13 (1984), assinado por Boaventura de Sousa Santos. Outro artigo de Graça Abranches (1984a), inserto neste último número, de novo convoca a teoria crítica para uma análise feminista das supostamente utópicas representações das mulheres e das relações amorosas no romance "cor-de-rosa" como formas de legitimação do statu quo. A contrastar com o contributo ambíguo, se não mesmo reaccionário, dos romances cor-de-rosa em prol da cidadania das mulheres, sobressai um artigo inserto no número 45, assinado ainda por Graça Abranches (1996), a dar conta de um importante trabalho pedagógico feminista na FLUC, com vista a "promover a igualdade entre homens e mulheres" (como rezava o art. 9 da Constituição de 1976). O título do artigo - "'Teacher, women can be nouns, too!'. A igualdade de oportunidades na formação inicial de docentes de Inglês” - reflecte o espanto de um aluno de uma cadeira de Didáctica do Inglês ao dar-se conta de que a notória inferiorização das mulheres na cultura é fruto tão-só de uma perversa e continuada construção social.

Em 1997 surgiu outro número especial dedicado à literatura ou, mais bem dito, à poesia. O número 47, organizado por Graça Capinha e Maria Irene Ramalho, tem por título "Os poetas e o social". Não fala de feminismo, fala só de poetas, mulheres e homens. Mas o modo como fazem falar

\footnotetext{
7 A convergência das lutas sociais feministas, incluindo classe, sexo e raça (e mais tarde outras condições humanas), haveria de adoptar o conceito de interseccionalidade, criado pela jurista marxista Kimberlé Williams Crenshaw no final do século passado (Crenshaw, 1989: 139-168). O n. ${ }^{\circ} 35$ da ex aequo. Revista da Associação Portuguesa de Estudos sobre as Mulheres (2017) inclui um amplo portefólio dedicado à interseccionalidade. É justo lembrar aqui que a necessidade de articular as lutas pela libertação das mulheres com as lutas de classe pela emancipação do proletariado foi formulada pela primeira vez na primeira metade do século XIX pela feminista e activista socialista francesa, Flora Tristán, em Union ouvrière (1843), obra dirigida "aux hommes et aux femmes" ["às mulheres e aos homens"] e "aux ouvriers et ouvrières" ["aos operários e às operárias"]. Consultado a 17.02.2018 em http://gallica.bnf.fr/ark:/12148/btv1b8626625v/f11.image. Ver também Tristán, 2007 e Collins e Weil-Sayre, 1972: 229-234. A notícia do assassinato em 14 de Março de 2018 da política brasileira, Marielle Franco - mulher, negra, favelada, lésbica, progressista, a quinta vereadora municipal mais votada do Rio de Janeiro - mostra de forma dramática a necessidade de continuar a articular as lutas em prol dos direitos sociais de todas as pessoas, incluindo pessoas envolvidas na política.
} 
o poético alguns dos poemas e ensaios incluídos, sublinhando a inteireza de estar na terra de Sophia, autoriza-nos desde já a sugerir que o poético é feminista (Ramalho, 2001a: 107-122).

Ao longo dos anos, embora nunca mais tivesse servido de tema a qualquer outro número especial, a literatura continuaria a surgir ocasionalmente na RCCS, por vezes tratada a partir de pontos de vista feministas ou, pelo menos, com a preocupação de dar maior visibilidade às mulheres, escritoras ou não. Assim acontece no número 68 (2004), subordinado ao tema "As mulheres e a Guerra Colonial", organizado por António Sousa Ribeiro e Margarida Calafate Ribeiro. Partindo do pressuposto de que a guerra é assunto masculino por excelência, o qual sempre deixa as mulheres envoltas em silêncio, "um silêncio demasiado ruidoso", como muito bem salienta Manuela Cruzeiro (2004) no seu título, o objectivo do número era reflectir "sobre a temática da Guerra Colonial de uma perspectiva feminina que focalizasse os vários aspectos históricos, sociais e políticos da questão, privilegiando, no entanto, a representação literária que foi pioneira na abordagem e tratamento multifacetado do tema" (Ribeiro e Ribeiro, 2004: 3; itálico das autoras). "África no feminino: as mulheres portuguesas e a Guerra Colonial", o artigo inaugural assinado por Margarida Calafate Ribeiro (2004), contextualiza o tema da guerra na tradição ocidental, mostrando como em todos os teatros bélicos, e também na Guerra Colonial, as mulheres sempre tiveram uma presença relevante, embora nunca devidamente reconhecida. ${ }^{9}$ Algumas esposas acompanharam os seus maridos combatentes e as ainda mais silenciadas mulheres locais foram muitas vezes usadas e abusadas de várias formas. Todos os restantes artigos se esforçam por dar visibilidade às mulheres numa esfera bélica onde, por definição, o "feminino" não poderia ter lugar e onde de facto ocorre - do ponto de vista feminista que, explícita ou implicitamente, inspira todos os artigos - exactamente do mesmo modo que existe na sociedade sexista em geral, ou seja, reservando às mulheres o papel ancilar de subordinação e de prestação de serviços que reflectem as tarefas "menores" tradicionalmente consideradas "femininas": o cuidado protector de mães ou irmãs ou "madrinhas", na retaguarda, e, na frente, o trabalho de enfermeiras ou faxineiras e o conforto sexual de esposas ou parceiras de ocasião, forçadas na maior parte das vezes estas últimas. Afinal, a ideologia capitalista, patriarcal e

\footnotetext{
${ }^{8}$ Para uma abordagem crítica, explicitamente feminista, da presença de mulheres em diferentes teatros de guerra, ver o número 96 da RCCS (2012), que analisamos infra neste artigo.

9 Três anos mais tarde, Margarida Calafate Ribeiro publicava um estudo mais alargado sobre o mesmo tema e com o mesmo título (Ribeiro, 2007). Para uma leitura feminista desta obra, ver a recensão de Vânia Duarte na RCCS 89 (2010), pp. 222-224.
} 
colonial da divisão sexual de funções e tarefas, amiúde referida nos artigos, pressupunha a abnegada dedicação das mulheres, anjos da paz, em prol do bem-estar dos homens, esforçados heróis da guerra pelo êxito pleno da missão imperial.

Com excepção do artigo de Helena Neves (2004), que recorre a entrevistas e tece considerações muito pertinentes sobre as consequências das experiências de guerra, as quais só aparentemente têm sido emancipatórias para as mulheres, a representação literária é a privilegiada. Romances de Wanda Ramos (Percursos (do Luachimo ao Luena), 1981) e Lídia Jorge ( A costa dos murmúrios, 1988) são objecto de análise em mais do que um artigo, em todos se reconhecendo, expressa ou tacitamente, que das obras delas, e de outras, traumatizadas testemunhas de guerras, se não pode falar sem ter em conta o sexo das suas autoras. Assim oportunamente refere Ana de Medeiros (2004) no seu estudo comparativo de $A$ costa dos murmúrios (1988), de Lídia Jorge, e L'amour, la fantasia (1985), da argelina Assia Djebar. Para falar de escritoras-testemunhas, como uma vez mais Lídia Jorge e Wanda Ramos, da tragédia que foi (e é) a Guerra Colonial portuguesa, convoca Roberto Vecchi (2004) a figura de Antígona. Na sua reflexão filosófico-literária sobre o trágico moderno, que muito deve ao pensamento feminista da filósofa italiana Adriana Cavarero, Vecchi ouve-lhes as vozes públicas, que de facto a cultura patriarcal misógina insiste em sonegar-lhes, e designa-as como "as Antígonas trágico-modernas da Guerra Colonial" (p. 94) ${ }^{10}$ Invocar figuras de mulheres ilustres da Antiguidade Clássica tem sido, de resto, gesto cada vez mais frequente em teóricas feministas para denunciar as leituras de sexista omissão que nos chegaram das origens da cultura ocidental. ${ }^{11}$ Também Maria Manuel Lisboa (2004) analisa uma divertida peça de Hélia Correia sobre a Grécia Antiga, intitulada $O$ rancor. Exercício sobre Helena (2000). Escrito com verve e fina ironia, e de uma perspectiva teórica inequivocamente feminista, o ensaio de Lisboa deixa as leitoras na dúvida sobre onde se regista a mais mordaz denúncia do secular sexismo da cultura a que chamamos nossa: na leitura hilariante que Hélia Correia oferece da Grécia Antiga ou na leitura dessa leitura que por sua vez oferece Lisboa. O último artigo do número 68, "Dois olhares e uma guerra", assinado por Laura Padilha (2004), não assume expressamente uma perspectiva feminista, antes se coloca inequivocamente do lado das lutas dos povos

\footnotetext{
${ }^{10}$ Cf. Cavarero, 2002. Vecchi cita o original: Cavarero, 1995a.

${ }^{11}$ Os vários livros da classicista feminista Page duBois vêm de imediato à memória, o último dos quais, Sappho (2015). Também Adriana Cavarero (1990; 1995b) revisita quatro outras figuras de mulheres da Antiguidade grega para redefinir a filosofia antiga: Penélope, a jovem serva da Trácia (mencionada de passagem por Platão no Teeteto), Deméter e Diotima.
} 
africanos pela libertação, por isso vendo a Guerra Colonial, por assim dizer do outro lado, como uma guerra anticolonialismo. O que é, em si, um gesto feminista, que a não deixa esquecer o sexo das suas poetas, a moçambicana Noémia de Sousa e a santomense Alda Espírito Santo, cúmplices ambas da teia de mulheres africanas em luta contra o "colosso colonial" (Santo, 1978: 181). Poderíamos dizer, parafraseando Sheila Rowbotham, que o fim do colonialismo de modo algum implica o fim do patriarcado. ${ }^{12}$

Dois anos mais tarde, a literatura voltou a protagonizar um novo número da RCCS. Organizado por António Sousa Ribeiro e Maria Irene Ramalho, o número 74 (Junho 2006) - "Modernismo(s)" - não evidencia, em geral, abordagens especificamente feministas. Com duas excepções: os ensaios de Paula Elyseu Mesquita (2006a) e Vivian Liska (2006). Com base em dois romances americanos da primeira metade do século xx, Paula Mesquita invoca Judith Butler (1990) para reflectir sobre a construção social do sexo e sobre a performatividade como subversão sociossexual. ${ }^{13}$ Vivian Liska, autora de uma obra sobre duas escritoras alemãs igualmente da primeira metade do século Xx, significativamente intitulado "Die Moderne - ein Weib" [O Modernismo - uma mulher] (2000), inclui na sua rigorosa indagação teórica sobre a dificuldade de identificar o que verdadeiramente se deve entender por "modernismo" um importante segmento acerca do contributo das teorias feministas para o alargamento do campo (Liska, 2006: 18-20). ${ }^{14}$

\section{Ciências Sociais e Feminismo}

No número 6 (1981), o segundo número temático da RCCS, dedicado à "Teoria das classes", surge um artigo de Virgínia Ferreira (1981), intitulado "Mulheres, família e trabalho doméstico no capitalismo". No Portugal dos anos 80 do século passado, a jovem socióloga vê-se confrontada com o contraste entre uma Constituição progressista, que impede a discriminação por razão do sexo, e a real subordinação das mulheres na sociedade portuguesa em geral. Sabendo bem que às leis no papel não corresponde necessariamente uma transformação imediata dos comportamentos e, muito menos, das mentalidades, Ferreira preocupa-se primeiro em entender a subordinação das mulheres nos países mais avançados, onde os fenómenos em causa estavam mais estudados. Claramente inspirada pela Escola de

\footnotetext{
${ }_{12}$ O número 68 inclui uma recensão crítica assinada por Tatiana Moura (pp. 169-173). Assumindo uma perspectiva desassombradamente feminista, Moura trata de uma obra que problematiza o papel das mulheres em teatros de violência e guerra: Mary Nash e Susanna Tavera (orgs.) (2003), Las mujeres y las guerras: el papel de las mujeres en las guerras de la Edad Antígua a la Contemporánea. Barcelona: Icaria.

${ }^{13}$ Da investigação que deu origem a este artigo, resultou ainda um livro: Mesquita, 2006b.

${ }^{14}$ Ver ainda Liska, 2000.
} 
Frankfurt, procede a uma análise das explicações oferecidas por pensadores como Marx, Engels, Max Weber, Horkheimer, Marcuse e Talcott Parsons sobre a velha distinção entre esfera pública/profissional e esfera privada/ /doméstica, sobre o que se entende por trabalho e sobre a relação entre a família e o capitalismo. Na sua perspectiva crítica, Ferreira recorre a obras de pensadoras feministas radicais, como Kate Millett (literatura; cf. Millett, 1970), Juliet Mitchell (psicanálise), Shulamith Firestone (sexo-enquanto-classe), cujas teorias muito contribuem, de ângulos diversos, para perceber que modos de transformação são mais adequados à subversão dos papéis sexuais e à libertação das mulheres. No final, contudo, Virgínia Ferreira parece encontrar mais afinidades com o pensamento da feminista socialista Sheila Rowbotham, cuja firme proposta de articulação entre o feminismo e o marxismo subscreve.

Quase uma década mais tarde, em outro número temático da RCCS (24, 1988: "Pós-modernismo e Teoria Crítica"), Virgínia Ferreira (1988), em "O feminismo na pós-modernidade", interroga-se sobre os caminhos do feminismo no momento pós-estruturalista, o da morte do sujeito e da proliferação das identidades, que alguns sectores convencionaram chamar pós-modernismo, ou pós-modernidade. Foi quando os conflitos entre diversas correntes ou posições teóricas, ou mesmo entre mulheres diferentes brancas, negras, heterossexuais, lésbicas, coloniais, pós-coloniais - e com objectivos diferentes - igualdade-diferença-redistribuição-reconhecimento-, pareceram pôr em causa a eficácia, ou até a necessidade, do feminismo. Falava-se já de pós-feminismo, como se o estatuto das mulheres na sociedade em geral não continuasse a ser o mesmo de sempre - exclusão, inferiorização, segregação, discriminação, opressão - e não fosse já necessário continuar a luta pela cidadania plena das mulheres. É evidente que a autora não pensava, nem pensa, assim - por alguma razão não encontrou ela na bibliografia de que se serviu uma definição de pós-feminismo.

Na RCCS 34 (1992), o terceiro volume resultante do I Congresso Luso-Afro-Brasileiro de Ciências Sociais, realizado em Coimbra em Julho de 1990, Virgínia Ferreira (1992) assina um outro artigo, intitulado "Informatização e feminização dos escritórios em Portugal”, onde conclui que, ao contrário do que ia acontecendo nos países mais avançados, em Portugal a informatização dos escritórios não favoreceu a entrada de mais mulheres no mundo do trabalho burocrático. O número que festeja os 20 anos da RCCS (52/53, 1998/1999: “Vinte anos de Teoria Social”) inclui mais um artigo de Virgínia Ferreira (1998/1999), intitulado "Os paradoxos da situação das mulheres em Portugal”. Acentua-se agora a perplexidade da autora perante a discrepância evidenciada entre as leis mais progressistas do mundo ocidental sobre 
o estatuto das mulheres em sociedade e a realidade da desigual redistribuição no terreno, no que respeita, por exemplo, aos salários bem mais baixos recebidos pelas mulheres para trabalho igual ao dos homens.

O número 34 de 1992 inclui mais três artigos de inspiração feminista. Em "Mulher, ciência e sociedade: abordagem das relações de gênero nas disciplinas da Universidade de São Paulo", duas sociólogas brasileiras, Eva Alterman Blay e Rosana da Conceição Ramos (1992), escrevem sobre a situação das mulheres no Brasil, em comparação com o que se passa em outros países ditos mais avançados, e concluem que, no que respeita à ciência e aos meios universitários, as mulheres brasileiras comparam favoravelmente com as norte-americanas, por exemplo. Reconhecendo, embora, a ainda escassa presença de disciplinas de Estudos sobre as Mulheres na Universidade de São Paulo, as autoras observam a existência crescente de perspectivas inovadoras, i.e. feministas, em certas áreas.

"Bruxas e bruxaria na Lagoa da Conceição: um estudo sobre poder feminino na Ilha de Santa Catarina”, assinado pela antropóloga brasileira Sônia Weidner Maluf (1992), trata de histórias de bruxas numa comunidade pesqueira do sul do Brasil colonizada por açorianos. Reflectindo sobre o rico imaginário europeu à volta da figura da bruxa, ora maléfica ora benéfica, mas sempre revestida de extraordinários poderes, Maluf observa que, tal como no Velho Mundo, as histórias que recolheu reflectem as esferas oficialmente separadas pela sociedade patriarcal dominante - homens/público/dominação; mulheres/privado/submissão -, as quais se sentem ameaçadas pela possível subversão de papéis e poderes na ordem social.

Nestes dois artigos brasileiros surge na RCCS, cremos que pela primeira vez, a palavra "género" para significar "diferença sexual", ou mesmo, simplesmente, "sexo". Já o artigo de Lígia Amâncio (1992), "As assimetrias nas representações do género", propõe-se teorizar o conceito de "género", enquanto constructo social independente do "sexo" (biológico), como fundamental para entender as dinâmicas de identificação e auto-identificação de homens e mulheres enquanto agentes sociais em diversas situações. No entanto, o termo, que curiosamente não é mencionado no resumo do artigo, parece referir-se apenas aos estereótipos do que se diz "masculino" ou "feminino" ou "andrógino", ou aos papéis sexuais socialmente construídos.

Em longo e muito bem informado artigo posterior, haveria Lígia Amâncio de descrever criticamente as várias discussões teóricas e as controvérsias acerca da importância e utilidade do conceito de género para as Ciências Sociais. Desse minucioso percurso, que passa pelo famoso ensaio 
da historiadora americana Joan W. Scott, "Gender: A Useful Category of Historical Analysis" (1986), Amâncio reconhece as limitações analíticas do conceito de género. ${ }^{15}$ Dada a origem anglo-saxónica do conceito (desde o século xv que os vocábulos sex e gender são sinónimos), talvez fosse de esperar a "corrupção do género pelo sexo", que Amâncio tanto lamenta (2003: 705). Afinal de contas, não parece ser possível falar de género sem falar de sexo e de sexualidade. ${ }^{16}$

Uma abordagem feminista da economia marca presença no número 111 da RCCS (2016), com o dossier "Finanças familiares, género e bem-estar no contexto da crise em Portugal", organizado por Lina Coelho e Catarina Frade. Em "Finanças conjugais, desigualdades de género e bem-estar: facetas de um Portugal em crise", a economista Lina Coelho (2016) argumenta a existência de relações de poder e de subordinação dentro da família, decorrentes de a quem é dada legitimidade para usar o dinheiro do agregado familiar - em casais heterossexuais e famílias nucleares, sublinhe-se -, constatando que as mulheres usufruem de um nível de bem-estar inferior ao dos seus companheiros, mesmo quando são elas que auferem maiores salários, verificando ainda que a situação tende a agravar-se com a maternidade.

Quem decide o que comprar e que conflitos subjazem a essas decisões no âmbito de um agregado familiar? O que se passa "dentro de portas" é de investigação difícil. Em "Methods of Studying Economic Decisions in Private Households", Erich Kirchler, Laura Winter e Elfriede Penz (2016) reflectem sobre as metodologias adequadas para uma investigação com o rigor possível. Estranhamente, o artigo não oferece uma perspectiva sexuada das dinâmicas de poder, que a questão pede. As dinâmicas de poder são, no entanto, abordadas, a partir da psicologia social no artigo seguinte, "Relação de poder entre cônjuges e representações sociais das estratégias de influência no casal", da autoria de Gabrielle Poeschl (2016). Haverá "estratégias femininas" versus "estratégias masculinas" no exercício do poder no âmbito de um casal? Baseado num estudo lato, o artigo conclui que apenas se podem analisar as representações, e não as práticas, confirmando a dificuldade do estudo das áreas ainda do domínio

\footnotetext{
${ }^{15}$ Lembramos um passo menos citado do ensaio de Scott (1986: 1053-1075), onde ela explica por que razão optou por Gender Studies [Estudos de Género], em vez de Women's Studies [Estudos sobre as Mulheres] ("pouco científico") ou Feminist Studies [Estudos Feministas] ("demasiado político").

${ }_{16}$ Ver "Feminism by Any Other Name", uma interessante conversa entre Rosi Braidotti e Judith Butler (1994) sobre as vantagens e desvantagens da opção pelos termos sexual difference [diferença sexual] ou gender [género] - cf. Ramalho, 2014: 124-143. Butler haveria mais tarde de prolongar o seu diálogo com Braidotti sobre termos do feminismo em Butler, 2004: 174-203.
} 
do privado. "A Gender Analysis of the Great Recession and 'Austericide' in Spain”, de Lina Gálvez e Paula Rodríguez-Modroño (2016), discute o agravamento das desigualdades entre os sexos no contexto da política austeritária dos últimos anos do Estado espanhol, concluindo que esta põe em perigo, inclusive, as conquistas conseguidas pelas mulheres nas últimas décadas.

O dossier inclui ainda recensões da autoria de Miguel Oliveira (2016) - Why Gender Matters in Economics, de Mukesh Eswaran - e de María León Molina (2016), do livro de Costanza Miriano, Cásate y sé sumisa: experiencia radical para mujeres sin miedo.

\section{Feminismo e cidadania europeia}

Em 1998, a RCCS abriu as suas páginas a uma selecção de artigos resultantes do Terceiro Congresso Europeu de Pesquisa Feminista, subordinado ao tema "Mulheres, mobilidade e cidadania" e realizado em Coimbra um ano antes. Organizado por Virgínia Ferreira e Teresa Tavares, o número 50 (1998) lança um olhar crítico multidisciplinar sobre as mulheres, e sobretudo as mulheres diaspóricas, na União Europeia no final do século xx. O número inclui artigos de especialistas de Ciência Política, Filosofia, Sociologia, Estudos Feministas e Literatura Comparada. O pano de fundo da pesquisa aqui incluída é a queda do Muro de Berlim em 1989, o desmantelamento da União Soviética em 1992, o Tratado de Maastricht assinado também em 1992 e a criação da União Europeia em 1993. Em reflexões que hoje a questão dos recentes refugiados torna mais prementes que nunca, as investigadoras aqui representadas olham a nova Europa e observam como o estatuto europeu, tal como o nacional, das mulheres está muito aquém do dos homens. Os artigos incluídos posicionam-se inequivocamente do lado das mulheres e revelam preocupações relacionadas com os problemas do reconhecimento e da redistribuição. Em "As mulheres, a cidadania e a sociedade activa”, Maria de Lourdes Pintasilgo (1998), ao mesmo tempo que louva a União Europeia por ter trazido desenvolvimentos favoráveis à cidadania das mulheres, como a consolidação dos Estudos sobre as Mulheres e a criação da Associação Europeia de Estudos sobre as Mulheres (AOIFE), ${ }^{17}$ mostra-se preocupada com a inexistência de um verdadeiro contrato sexual

\footnotetext{
${ }^{17}$ Em 1996, no âmbito do projecto SIGMA e por iniciativa de Rosi Braidotti, a União Europeia criou a AOIFE (Association of Institutions for Feminist Education and Research in Europe, que o mesmo é dizer Associação Europeia de Estudos sobre as Mulheres). Da AOIFE (leia-se "Ifa", "Eva" em gaélico) resultaram várias outras organizações, desde 2007 subsumidas em ATGENDER (The European Association for Gender Research, Education and Documentation). Ver https:// atgender.eu/.
} 
que corrija a desigualdade de mobilidade e oportunidade de mulheres e homens no universo europeu. Em "A nova 'outra' mulher europeia", Joanna Regulska (1998) escreve sobre o impacto da União Europeia nas mulheres da Europa Central e de Leste, as quais se vêm agora identificadas como "a Outra" - económica, política e culturalmente. Em "A diferença sexual e o controverso conceito de cidadania europeia”, Rosi Braidotti (1998) retoma o conceito de uma "Fortaleza Europa" para sublinhar as suas inclusões e exclusões e insistir na necessidade de a Europa tomar consciência das identidades nómadas, sobretudo de mulheres, que passaram agora a constituí-la. Em "Invisíveis, diabolizadas, instrumentalizadas: figuras de mulheres migrantes e suas filhas na Europa", Françoise Gaspard (1998), se bem que atendendo apenas ao caso especial das migrações em França, regista a pressão que as comunidades sempre põem sobre as mulheres como supostas ideais apaziguadoras do privado e do pessoal, por isso, sem acesso ao público e ao político elas próprias. Em "Mulheres migrantes: uma abordagem a partir da teoria das redes", Fortunata Piselli (1998) serve-se do conceito de rede para mostrar como as migrações continuam a deixar às mulheres as tarefas de consolidação das comunidades migrantes mediante as relações de parentesco, cuidado e solidariedade. Também Louise Ackers (1998), em “'Cuidar de longe': mulheres, mobilidade e autonomia na União Europeia", põe a nu a fragilidade e dependência das mulheres migrantes, com menos autonomia ainda do que nos países de origem. ${ }^{18} \mathrm{Em}$ "Mulheres em diáspora na União Europeia: percursos migratórios e trajectórias profissionais e familiares", Heloísa Perista (1998) recorre a entrevistas em profundidade para estudar as dificuldades profissionais de mulheres migrantes em Portugal. Em "Tomando a dianteira: mulheres e emigração em regiões desfavorecidas", Manuela Ribeiro (1998) estuda o impacto da mobilidade das mulheres rurais no processo de desagrarização do nosso país. Finalmente, em "A nação em transculturação e os espaços sexualmente diferenciados da diáspora: Mulher/Homem e cidadania”,

\footnotetext{
${ }^{18}$ Os artigos de Gaspard, Piselli e Ackers remetem para a questão da "sociedade-providência", discutida na RCCS 42 (1995). Criado na década de 1980 por Boaventura de Sousa Santos para explicar como as falhas do Estado-providência em Portugal eram largamente supridas por relações de parentesco, amizade e entreajuda, o conceito de sociedade-providência desde logo se deu conta de que o cuidado exigido teria de ser em larga medida da responsabilidade das mulheres, que assim eram uma vez mais relegadas para o "doméstico" e excluídas da cidadania. Ou da "esfera do masculino", ou da "cidadania civil", como lhe chamam as feministas americanas, Linda Gordon e Nancy Fraser, em artigo incluído nesse mesmo número ["Contrato versus caridade. Porque não existe cidadania social nos Estados Unidos?”, pp. 27-52]. No seu Editorial, Santos sublinha, entre os lados negativos da sociedade-providência, "ausência de direitos, discriminação sexual das mulheres, paternalismo nas relações” (RCCS 42, p. vi).
} 
Mary Layoun (1998) mostra como a poesia e a ficção tratam as questões de cidadania, mobilidade, diferença sexual e desigualdades de modo bem mais eloquente do que qualquer estudo analítico sobre o tema. $\mathrm{O}$ poético é feminista. ${ }^{19}$

\section{Feminismo e Estudos Queer}

O número 76 da RCCS, "Estudos Queer: identidades, contextos e acção colectiva", de 2006, sinaliza a ainda muito recente, mas crescente, visibilidade da teoria queer em Portugal na primeira década do século XXI. As dificuldades em definir-se enquanto campo autónomo - muito semelhantes, de resto, às dificuldades igualmente sentidas pelos Estudos Feministas - são discutidas na introdução deste número pela mão de Ana Cristina Santos (2006a), sua organizadora. A autora afirma ao que vem: fazer uma "arqueologia conceptual", perante a dificuldade colocada pela categoria Estudos Queer, herdeira simultaneamente dos Estudos Feministas e dos Estudos Gays e Lésbicos. A diversidade de perspectivas e posicionamentos disciplinares recolhidos neste volume faz um estado da arte em 2006 e cumpre cabalmente o propósito da sua organizadora. ${ }^{20}$

Em "O casamento entre pessoas do mesmo sexo. Sobre 'gentes remotas e estranhas' numa 'sociedade decente'”, Miguel Vale de Almeida (2006) expõe os argumentos e os paradoxos da reivindicação do direito ao casamento por parte de casais do mesmo sexo. Começando por fazer uma ressalva quanto ao "carácter politizado dos discursos científicos convocados para o debate" (p. 17), Vale de Almeida sublinha a importância do reconhecimento, pelo poder legitimador, de práticas já existentes. As reservas colocadas a esta reivindicação por parte da comunidade LGBT portuguesa fundam-se, argumenta, no paradoxo de se exigir o acesso a uma instituição tida como conservadora. Por outro lado, o autor sublinha a importância dos materiais

\footnotetext{
${ }^{19} \mathrm{O}$ número 50 inclui ainda recensões de duas obras feministas. Menina e moça. A construção social da feminilidade. Séculos XVII-XIX de Teresa Joaquim (1997) é lida por Teresa Pinto, que salienta a influência de Luce Irigaray no pensamento da autora; Teresa Joaquim, por sua vez, assina uma recensão de Mulheres sem sombra. Maternidade e novas tecnologias de reprodução, da psicanalista argentina sediada em Espanha, Silvia Tubert (1996 [1991]), cuja tradução em língua portuguesa tinha acabado de ser publicada no Brasil.

${ }^{20}$ Desde então muito aconteceu: em 2018, as identidades bissexuais, transgéneros e intersexo - cuja ausência está identificada em 2006 - e a teoria-chapéu a elas ligada tornaram-se incontornáveis. De notar que o acrónimo LGBT, usado "naturalmente" em 2006, hoje teria de ser substituído por LGBTQ, ou LGBTI, ou ainda LGBTQI, o que reflecte o alargamento das políticas identitárias no sentido de uma inclusão cada vez mais lata, ou, noutros termos, a reformulação do sujeito dos Estudos Queer. Para um importante contributo neste sentido nas páginas da RCCS, ver Ana Lúcia Santos (2013).
} 
simbólicos e da reconfiguração de instituições como a família, parentalidade e reprodução, de modo a desvincular as práticas sociais do biológico. ${ }^{21}$

Gabriela Moita (2006), em "A patologia da diversidade sexual: a homofobia no discurso de clínicos", analisa a persistência de uma "moral religiosa", reformulada como "moral de saúde" entre os profissionais de saúde mental em Portugal, expressa na sua relação com clientes homossexuais e lésbicas. Tendo analisado depoimentos de clínicos e de clientes, Moita conclui que a homossexualidade continua a ser percepcionada como défice ou falha, o que é evidente na análise de discurso dos exemplos incluídos no artigo. Quando não passível de "correcção", procuram-se explicações para o "desvio" na infância em experiências traumáticas, ou ainda em experiências anteriores não satisfatórias com pessoas do sexo oposto. De sublinhar a persistência destas representações de "norma" e de "desvio", mesmo em profissionais que defendem o direito a práticas sexuais não normativas por parte de quem os procura e que têm de si próprios a percepção de não serem pessoas homofóbicas. ${ }^{22}$

Em " 'Do anel à aliança': sentido dos iguais e emancipação pessoal na psicologia das sexualidades", Nuno Santos Carneiro e Isabel Menezes (2006) abordam as sexualidades contemporâneas a partir da psicologia social, disciplina cujo enfoque se encontra nas "estruturas sociais, culturais e políticas nas quais a construção do sentido de si vai ocorrendo" (p. 80). Se o sujeito se constrói em interacção com o social e os seus mecanismos de regulação, acontece que os contextos são infinitamente plurais e multiformais. Se a esta infinita multiplicidade acrescentarmos a irredutível singularidade do sujeito na sua dimensão psicológica, o artigo confronta-se com uma impossibilidade: como identificar um padrão em materiais definidos pela multiplicidade, singularidade e devir? Outra ambição deste ensaio é a da conciliação entre a análise psicológica (singular) da vida sexual e uma teorização pós-identitária das sexualidades. Já em 2004 Fernando Cascais estabelecia a diferença entre os Estudos Gays e Lésbicos, fundados em "identidades fortes", e os Estudos Queer, cujo objectivo seria superar as lógicas e os discursos identitários que inevitavelmente escorregam para concepções binárias e, no limite, normativas (Cascais, 2004). Mas como conceptualizar "papéis

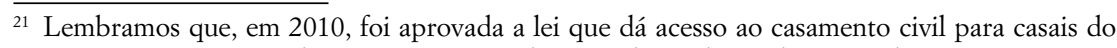
mesmo sexo, em 2011, a lei que cria o procedimento de mudança de sexo e de nome próprio no registo civil, ao passo que o direito à adopção homoparental foi garantido em 2016. Se as práticas são agora reconhecidas pela lei, o trabalho sobre os materiais simbólicos, particularmente no que diz respeito à homoparentalidade, a própria reconfiguração do parentesco e do que se entende por "cuidado" é um trabalho ainda e sempre em curso.

${ }^{22}$ Este trabalho apresenta resultados parciais da investigação desenvolvida pela autora para a sua tese de doutoramento. Ver Moita, 2001.
} 
sociais" sem a identificação, ainda que provisória ou volátil, de comunidades de pertença? Parece-nos que, ao falar de contextos e de um sentido de pertença situado, é ainda de identidades que estamos a falar, e esta é uma das aporias dos Estudos Queer. Carneiro e Menezes identificam correctamente este problema conceptual ao afirmar que a teoria queer corre o risco da erosão das especificidades e, ao destruir o identitário, acaba por incorrer no risco da apatia política. Acresce ainda que uma relação com "os iguais", sustentam os autores, é potenciadora da emancipação pessoal.

Reconhecido pioneiro da área de Estudos Queer em Portugal, em "Diferentes como só nós. O associativismo GLBT português em três andamentos”, Fernando Cascais (2006) esboça uma cronologia e faz uma análise das últimas quatro décadas. Com particular atenção ao rigor histórico, Cascais sublinha a especificidade portuguesa. Sem surpresa, identifica a emergência destes movimentos "no seio da tradição e com os materiais do património emancipatório das esquerdas" (p. 110). Por outro lado, se os movimentos só foram tornados possíveis pela Revolução de 1974, esta "não foi condição suficiente para a sua emergência" (p. 125), o que o contexto de oposição ao regime, primeiro e, mais tarde, o contexto revolucionário de alguma forma explicam. De facto, a (então chamada) "questão homossexual" - como a (então chamada) "questão da mulher" - nunca constaram das agendas das forças da oposição democrática nem das forças revolucionárias, concentradas que estavam noutros combates. A ausência de receptividade à emancipação homossexual - e à emancipação das mulheres, acrescentamos nós - nas esquerdas portuguesas, por alturas da Revolução, é sublinhada por comparação com a Europa do Norte e mesmo com a Espanha. Toda a cronologia proposta por Cascais é, de resto, marcada por este aparente paradoxo da esquerda portuguesa, particularmente a esquerda ortodoxa - mais exactamente o Partido Comunista Português - cuja "moral revolucionária" é defensora das "virtudes másculas", que reforçam o heterossexismo e a homofobia (p. 113). Acresce ainda que, segundo o autor, a "cultura científica positivista" das esquerdas portuguesas se encontra também nas universidades, que permaneceram estanques a estas questões durante muito tempo - tal como acontece com o feminismo ortodoxo. Uma outra especificidade portuguesa, segundo Cascais, reside no impacto que a epidemia de SIDA teve no país: a mobilização da classe médica e das organizações não-governamentais na luta contra a doença "proporcionaram ao associativismo as necessárias dinâmica e legitimidade" (p. 125); a sua autoridade científica terá desautorizado os discursos homofóbicos, calando nomeadamente a hierarquia da Igreja Católica (p. 118). Ao concluir a história dos últimos 40 anos, Cascais identifica um "limite de crescimento" e "o início de uma reacção anti-emancipatória" (p.124), 
diagnóstico entretanto desmentido e que constitui mais um exemplo da impossibilidade de prever o futuro.

Das fracturas e das pontes entre os movimentos e a academia trata o artigo de Ana Cristina Santos (2006b), "Entre a academia e o activismo: sociologia, estudos queer e movimento LGBT em Portugal". Fundando-se na ideia da "sociologia pública", a autora avança para a proposta de construção de pontes entre a investigação e os movimentos sociais numa relação de horizontalidade e complementaridade. Esta é uma relação que já se verifica no terreno, mas que não é isenta de tensões, sempre perpassada por uma assimetria de poderes, onde se confrontam reivindicações de autoridade. Estas tensões fazem parte do processo de negociações sempre em curso; aliás, poderíamos argumentar que reside aqui justamente parte do dinamismo, tanto dos Estudos Queer e dos Estudos Feministas, como dos próprios movimentos.

Sasha Roseneil (2006), em "Viver e amar para além da heteronorma: uma análise queer das relações pessoais no século Xxı", argumenta a necessidade de reconfigurar as representações da família e dos afectos, defendendo que a sociologia precisa de "desalojar o casal heterossexual do lugar central que ocupa no nosso imaginário intelectual” (p. 34). A proposta de uma sexualidade e de uma afectividade fluidas, que aqui se encontra, é interessante também na medida em que supera as "identidades fortes" (Cascais, 2004) dos Estudos Gays e Lésbicos. Ora, este artigo propõe um modelo de afectividade, de intimidade e de cuidado para além de qualquer norma, deslocando-as para as relações de amizade em rede. Para além de desvincular a afectividade da sexualidade, esta proposta desestabiliza ainda o binómio homossexual/ /heterossexual, defendendo que pessoas de uma e outra orientação sexual têm modos de vida progressivamente mais convergentes. ${ }^{23} \mathrm{O}$ autor conclui afirmando a necessidade da queerização do estudo da "vida pessoal", isto é, da problematização das culturas da intimidade e do cuidado.

Se os Estudos Queer não se deixam dizer exactamente, na sua fluidez e indeterminação, é no artigo de Michael O'Rourke (2006), "Que há de tão queer na teoria queer por-vir?”, que esta ideia é mais evidente. $\mathrm{O}$ autor assume explicitamente este seu ensaio como parte de um trabalho de luto por Derrida e, de facto, entretece citações do filósofo então recentemente falecido com as suas próprias reflexões sobre o queer, de modo que é frequentemente difícil destrinçar as duas vozes em presença. Conceitos de Derrida - particularmente o voyou [vadio], a hospitalidade e a auto-imunidade -

${ }^{23}$ Este ensaio é baseado no trabalho desenvolvido pelo autor num projecto de investigação, significativamente intitulado "Care, Friendship and Non-Conventional Partnership Project". 
são usados para reflectir sobre o "indeterminável, monstruoso e até vadio futuro dos estudos queer" (p. 127). O’Rourke não propõe cenários futuros, mas concentra-se na identificação de um "estado de paralisia" só superável por abertura radical a um Outro desconhecido. Esta seria uma "teoria vadia" resistente tanto à institucionalização como às políticas identitárias. O queer quebraria, assim, as "amarras teóricas" às sexualidades para se abrir a todas as preocupações sociais e à transformação da ordem mundial.

Este número inclui ainda recensões de obras atinentes à área de Estudos Queer assinadas por Ana Cristina Santos, Anabela Rocha e Telmo Fernandes.

\section{Feminismo, cidadania e outros saberes}

Em 2010, surgiu um número temático inteiramente dedicado ao pensamento feminista (RCCS 89). Organizado pelas autoras do presente artigo, ambas responsáveis pela criação do programa de Estudos Feministas na FLUC (2007-), uma área disciplinar à época não unanimemente reconhecida pela academia, o número sugere, logo pelo título - "Estudos feministas e cidadania plena" -, as preocupações científico-pedagógicas das organizadoras. Numa altura em que se começara a falar de pós-feminismo, não particularmente no sentido de alargar o âmbito dos saberes e das lutas, mas antes no sentido de dar por concluído o trabalho em prol da plena cidadania das mulheres, a qual teria já sido atingida, Adriana Bebiano e Maria Irene Ramalho organizaram um colóquio internacional, que obrigou a Universidade de Coimbra a reflectir seriamente sobre a problemática do feminismo. Desse colóquio resultou este número especial da RCCS.

O número reúne ensaios de doze especialistas de áreas diversas, que lançam um olhar epistémico feminista sobre os temas de que se ocupam, da filosofia à ciência política, da literatura às artes plásticas, da sociologia e antropologia ao direito, da teologia à poesia lírica. Com excepção do artigo de Carole Pateman, a perspectiva marcante neste número é a do reconhecimento.

Em "Concepções filosóficas e representações do feminino: subsídios para uma hermenêutica crítica da tradição filosófica”, Fernanda Henriques (2010) revisita a filosofia antiga para demonstrar que a dominação masculina, que continua a persistir na nossa cultura, nem é "natural" nem foi sempre aceite sem contestação, mesmo no nosso passado remoto. À semelhança de outras filósofas feministas a que já fizemos referência, também Fernanda Henriques convoca, em prol do seu argumento, uma figura feminina da Grécia Antiga, Aspásia, que decididamente não se limitou a ser a amante de Péricles. Considera, pois, Henriques imperativo reconfigurar o nosso presente e o nosso futuro com equidade, recontando a história, ou seja, dando 
conta dos seus silêncios e dos seus vieses, a fim de reavaliar e reinterpretar a nossa herança cultural em prol do nosso futuro. "Recontar a história" é, aliás, um conceito que Fernanda Henriques colhe de Paul Ricoeur, um filósofo cuja racionalidade, entretecida do poético, a autora considera particularmente fecunda para o desenvolvimento do pensamento feminista. ${ }^{24}$

Curiosamente, mas não por acaso, tanto a filósofa Fernanda Henriques como a teóloga Teresa Toldy, para falar da nossa herança, invocam The Dinner Party, a famosa instalação colectiva e colaborativa de Judy Chicago. ${ }^{25}$ A ambas serve The Dinner Party de poderosa metáfora de algumas das desocultações que urge levar a cabo para construir uma sociedade mais equitativa e mais justa. Também Teresa Toldy entende o seu trabalho enquanto teóloga feminista como um recontar (diferente) da tradição, no caso, um recontar do cânone da religião cristã que permita denunciar o cruel absurdo da inferiorização das mulheres e a inevitabilidade da sua emancipação. Em "A violência e o poder da(s) palavra(s): a religião cristã e as mulheres", Teresa Toldy (2010a) põe a nu a imagem grotesca que das mulheres ressalta de textos bíblicos e patrísticos - criaturas inferiores na escala do ser, cujo potencial perverso foi sempre necessário coarctar, reduzindo-as ao servilismo doméstico ou, na melhor das hipóteses, ao lar, à submissão conjugal e à maternidade. Por alguma razão, em tanta literatura ou arte produzida por mulheres se encontram representações de mulheres que deliberada e ousadamente desafiam o decoro social. ${ }^{26}$ Socorrendo-se sobretudo do pensamento de Elisabeth Schlüssler Fiorenza (1998), Teresa Toldy mostra como o conhecimento desse autêntico monumento de submissão e degradação das mulheres, que é o cânone religioso, incluindo as mais recentes encíclicas de bem-intencionada dignificação das mulheres, é fundamental para o desconstruir e definitivamente derrubar a ideologia patriarcal, que continua a negar às mulheres o direito de ser-próprio. A perspectiva extremamente crítica de Toldy não implica, porém, a rejeição da religião. Pelo contrário. Em outro artigo, com a mesma data e também

\footnotetext{
${ }^{24}$ As ideias apresentadas neste artigo de Fernanda Henriques viriam a ter alargamento e aprofundamento em livro recente (ver Henriques, 2016). Para uma excelente recensão desta obra, ver Pires (2017: 226-230).

${ }^{25}$ Lembramos que The Dinner Party (1974-79) apresenta uma versão simbólica da história do Ocidente, prestando homenagem a 39 mulheres notáveis: "Da Pré-história a Roma", "Do Cristianismo à Reforma", "Da Revolução Americana à Revolução das Mulheres". A utilização que a artista faz na instalação do corpo da mulher, dando aos pratos a forma de uma vulva (modo radical de tornar político o pessoal), continua tanto a deslumbrar como a escandalizar. Para uma crítica do eurocentrismo da instalação, ver Spillers (1984: 73-100). Sobre a obra de Judy Chicago e as controvérsias que suscita (dentro e fora do feminismo), cf. Gerard (2013).

${ }^{26}$ Cf. Bebiano (2009: 21-36; 2017: 11-25). A atenção feminista prestada por Bebiano à formatação social de personagens femininas em textos literários vem de longe (cf. Bebiano, 1994).
} 
publicado na RCCS, ao mesmo tempo que reconhece que tanto o religioso como o secular podem ser manipulados com péssimas consequências para a cidadania das mulheres, Toldy reflecte sobre a possibilidade de um discurso pós-colonial e pós-secularista sobre os direitos humanos e das mulheres descobrir o potencial emancipatório de feminismos de inspiração religiosa (Toldy, 2010b: 5-24). A este tema voltaremos mais à frente.

Contrastando com a imagem misógina da tradição que nos revelam Henriques e Toldy, o classicista Carlos André (2010) oferece-nos uma visão aparentemente não sexista do mundo antigo. Em "A ironia ovidiana na subversão do protocolo amoroso em Roma”, uma revisitação de Ovídio, o autor mostra a ambiguidade da Roma Antiga em relação às mulheres: se as leis e as práticas sociais lhes cerceavam os direitos e as confinavam ao gineceu, nos poemas estudados por André encontramos representações poéticas de paridade na relação amorosa que parecem reconhecer às mulheres dimensões ausentes do discurso público dominante. A obra de Ovídio em geral, dir-se-á, contradiz esta interpretação. Mas a verdade é que, em todos os passos citados, é legítimo vislumbrar uma persistente ironia, quem sabe se, como defende André, subtilmente apostada em minar e subverter os fundamentos do protocolo amoroso, de matriz inequivocamente masculina, da Roma de Augusto. Como sugere a comparatista Mary Layoun no artigo citado acima, e como mostra Rosemarie Buikema no artigo de que falamos a seguir, a literariedade - ou o poético - tem o poder de re-imaginar o social de formas emancipatórias.

Em "O conteúdo da forma e outras políticas textuais. Configurações de nação e cidadania em Disgrace e Agaat", Rosemarie Buikema (2010) debruça-se sobre dois celebrados romances da África do Sul pós-apartheid, para entender como a literariedade e as políticas de representação se conjugam para a construção da identidade e da diferença, da comunidade e da cidadania. Observando os contextos e circunstancialismos da publicação tanto do romance Disgrace de J. M. Coetzee (1999) como do romance Agaat de Marlene van Niekerk (2006), e analisando a recepção polémica de cada um deles, Buikema sugere que a narrativa de ficção coloca questões importantes relacionadas com as subjectividades e as políticas de identidade. Romances complexos e controversos, como Disgrace e Agaat, são guias preciosos para a exploração da interacção de forma e conteúdo, literariedade e política, literatura e cidadania. À crítica literária feminista não interessa só o sexo de quem escreve; interessa, sobretudo, a teia de relações sociossexuais que transparece na escrita.

Um olhar de outro tipo sobre a injustiça e a opressão contra as mulheres na nossa cultura lança a cientista política Carole Pateman (2010) em 
"Garantir a cidadania das mulheres: a indiferença e outros obstáculos". Reconhecendo, embora, que a posição social e económica das mulheres, e bem assim a sua situação política, jurídica e cívica, melhoraram muito ao longo de todo o século xx, Pateman não poderia hoje senão responder negativamente à pergunta com que termina o seu primeiro parágrafo: "serão as mulheres hoje cidadãs de pleno direito em todos os países do mundo?". ${ }^{27}$ Carole Pateman tem dedicado grande parte da sua obra a explicar que a cidadania plena das mulheres tem sido difícil de alcançar, mesmo nos países ditos mais avançados, porque as estruturas de poder a obstruem sistematicamente. $\mathrm{O}$ poder nunca abdica dos seus privilégios sem luta, e a milenar dominação masculina que continua a reger-nos não é excepção. A melhoria de que se fala acima foi resultado de muitas lutas, mas as concepções dominantes de masculinidade, feminilidade e outras - classe, raça, etnicidade - cultivam a indiferença e continuam a relegar as mulheres para papéis secundários e mesmo degradantes, e a deixá-las muitas vezes à mercê da mais selvática violência. A indiferença, como obstáculo à equidade, é um conceito fundamental para Pateman. Indiferença, por exemplo, perante as gritantes desigualdades económicas que maioritariamente atingem as mulheres, excluídas do contrato social por Rousseau. Por isso, invocando Mary Wollstonecraft, defende Pateman a política do rendimento básico, que vê como um contributo possível para a redistribuição com vista à independência económica das mulheres, ainda hoje tantas vezes impedidas de aceder a trabalho assalariado - onde de qualquer modo ganharão decerto menos do que os homens - pelo trabalho-sombra das suas tarefas familiares não remuneradas. ${ }^{28}$ Imaginamos que Pateman terá ficado satisfeita ao saber que a Islândia acaba de fazer mais uma diligência no sentido de tornar efectivamente ilegal discriminar os salários por razão do sexo, uma discriminação

\footnotetext{
${ }^{27}$ Basta prestar atenção aos meios de comunicação social para saber como muitas mulheres, só por serem mulheres, e sobretudo mulheres pobres e racializadas, continuam a ser vilipendiadas, torturadas e assassinadas no mundo inteiro. Casos como o que aqui se conta ainda são hoje mais a regra do que a excepção: cf. María Eugenia R. Palop, eldiario.es, 11 de Janeiro 2018, consultado a 12.01.2018 em http://www.other-news.info/noticias/2018/01/mujer-migrante-ycuidadora-victima-de-la-pobreza-y-de-la-violencia-machista/\#more-14430.

${ }^{28}$ Lembramos que é de Mary Wollstonecraft, em A Vindication of the Rights of Woman (1792), a primeira denúncia feminista do discriminatório Contrato social de Rousseau (1762). Uma excelente edição recente: Wollstonecraft, 2014. Foi também Wollstonecraft a primeira pessoa a insistir na independência económica como a condição essencial da dignificação do ser-mulher. Para tal, em seu entender, teriam as mulheres de ter acesso a uma educação adequada, como a autora defende na introdução-carta-dedicatória dirigida a Charles Maurice de Talleyrand-Périgord. Em relatório apresentado à Assembleia Nacional Francesa em 1791, Talleyrand-Périgord opinara que às mulheres deveria ficar reservada apenas uma educação para o doméstico.
} 
que alegadamente a BBC continua a fazer. ${ }^{29}$ Por outro lado, as cada vez mais abissais discrepâncias económicas no mundo em geral não nos permitem ser hoje tão optimistas acerca da existência de um crescente apoio popular à política do rendimento básico, como Pateman sugeria há dez anos.

Esta questão leva-nos a considerar a importância do chamado feminismo de Estado. Parece de aclamar qualquer intervenção do Estado no sentido de apoiar os direitos sociais das mulheres, como no caso da projectada ilegalização islandesa de salário diferente para trabalho igual por razão do sexo. Também a Bolsa Família no Brasil, a que Pateman faz referência, é legislação favorável ao bem-estar dos pobres, mulheres na sua maior parte. Em "Da delegacia da mulher à Lei Maria da Penha: Absorção/tradução de demandas feministas pelo Estado", Cecília MacDowell Santos (2010) dá-nos conta de um outro exemplo brasileiro que mais adequadamente se pode articular com o conceito de feminismo de Estado. Trata-se das demandas feministas que a partir do final da década de 1980 levaram o Estado a intervir em casos de violência contra as mulheres, antes considerados acidentes banais do foro privado. À criação das delegacias da mulher - postos policiais constituídos exclusivamente de agentes do sexo feminino, mas não necessariamente sensíveis à problemática feminista que denuncia a violência contra as mulheres - seguiu-se a promulgação de leis para melhor lidar com as agressões corporais, de que as mulheres eram maioritariamente vítimas. O que se torna mais interessante para quem lê este artigo é a análise que a autora oferece dos prós e contras do feminismo de regulamentação estatal. Cecília MacDowell Santos fala de "traição" por parte do Estado na adopção das propostas feministas sobre o âmbito e alcance dos textos legais e das políticas públicas. Como bem explica Rosa Monteiro em artigo de outro número da RCCS, os governos progressistas são um pouco mais favoráveis a legislação que proteja os interesses das mulheres, mesmo que a política continue, em larga medida, a conjugar-se no masculino (Monteiro, 2011). Com a expansão global do neoliberalismo e a direita a voltar em força aos poderes, terão as mulheres muito a esperar do feminismo de Estado?

Tão mais de louvar as lutas em que continuam a empenhar-se pessoalmente as mulheres por uma identidade digna, mesmo em condições de extrema precariedade, como as das migrações e diásporas forçadas do

\footnotetext{
${ }_{29}$ Ver https://www.nytimes.com/2018/01/03/world/europe/iceland-equal-pay.html (3 de Janeiro de 2018); https://www.nytimes.com/2018/01/07/business/media/bbc-gender-pay-gap.html (7 de Janeiro de 2018). A discriminação racial continua também, relata o The Guardian (4 de Março de 2018): https://www.theguardian.com/commentisfree/2018/mar/04/employers-gender-paygap-race-ethnic-minority. Páginas consultadas a 04.03.2018. Donde mais uma vez se conclui da importância da interseccionalidade.
} 
nosso tempo, de que nos fala Teresa Cunha (2010) em "Imobilidades e fracturas: mulheres, identidades e narrativas viajantes em Timor-Leste". Teresa Cunha debruça-se aqui sobre o sentimento paradoxal de pertença e não-pertença de algumas mulheres diaspóricas de Timor-Leste, empenhadas na construção da nova nação. A verdade é que, como revelam os testemunhos recolhidos pela autora, a situação das mulheres em todo o processo pós-colonial de libertação, no campo da luta como na diáspora, continua a ser de extrema dependência e subalternidade. O que não impede os gestos de rebeldia e transgressão com que as mulheres negoceiam a sua identidade e reinventam os seus papéis para uma sociedade que desejam bem mais justa e igualitária do que a anterior sociedade colonial. Um tal desiderato exige, como demonstra este artigo, a convergência - ou interseccionalidade - de vários factores: de sexo, raça e classe, evidentemente, mas também do político - coisas supostamente só de homens - e do pessoal - coisas supostamente só de mulheres. ${ }^{30}$

Em "A instância corpórea do humano: sexualidades e subjectividades, mulheres e ética", Isabel Allegro de Magalhães (2010) teoriza sobre identidade e diferença à luz da re-materialização do pensamento feminista proposta por filósofas deleuzianas, como Rosi Braidotti (2000 e 2001) ou Elizabeth Grosz (1994 e 2017). O artigo, que abre com uma epígrafe de Virginia Woolf, a que voltaremos ("I am rooted, but I flow"), começa por fazer um apanhado da evolução do pensamento feminista ocidental a partir daquilo a que chamámos já a segunda vaga do feminismo: a década de 1960 nos Estados Unidos da América (EUA), com as mulheres a negarem os rótulos de domesticidade subordinada que o patriarcado lhes coloca no corpo e no sexo, e a década de 1970 em França, com a Simone de Beauvoir de $O$ segundo sexo (1949) bem presente. A autora distingue, no entanto, as formas diferentes como as feministas norte-americanas e as francesas concebem a reivindicação do corpo. As norte-americanas reclamam libertar o corpo do controlo da ideologia e dominação patriarcais, ao passo que as francesas estão sobretudo preocupadas em identificar e teorizar uma escrita produzida pelos corpos situados e sexuados das mulheres. Écriture féminine assim entendida: "Il faut que la femme s'écrive: que la femme écrive de la femme et fasse venir les femmes à l'écriture, dont elles ont été eloignées aussi violemment qu'elle l'ont été de leurs corps" [É preciso que a mulher se escreva: que a mulher escreva da mulher e traga as mulheres

\footnotetext{
${ }^{30}$ Lembramos que o conceito de que "o pessoal é político" tem origem num ensaio da feminista norte-americana Carol Hanish do final da década de 1960, hoje facilmente acessível em http:// www.carolhanisch.org/CHwritings/PIP.html.
} 
à escrita, de onde foram tão violentamente afastadas quanto dos seus corpos" (Cixous, 2010 [1975]: 37). ${ }^{31}$ Atenta aos desenvolvimentos posteriores de teorizações de cariz feminista, sobretudo a partir do impacto de Gender Trouble de Judith Butler (1990) e de A Cyborg Manifesto (1991 [1984]) de Donna Haraway na questionação do próprio conceito de "diferença", Isabel Allegro termina, manifestando receio de que deixe de ser possível considerar mulheres corpóreas concretas em sociedade. Uma tal preocupação, manifestada logo em 1998 por Wendy Brown (2005: 116-135), uma cientista política que receia o advento de um feminismo sem mulheres, poderá talvez ser infundada, se tivermos em conta todo o trabalho de Braidotti, a teórica feminista que aqui visivelmente inspira Isabel Allegro de Magalhães, e que tão eloquentemente soube escrever sobre a positividade da diferença (Braidotti, 2001). ${ }^{32}$ Retomando a epígrafe retirada de Virginia Woolf, a escritora que melhor representou nos seus romances o frágil e fluido devir da diferença (sexual), como amplamente salientam Deleuze e Guattari (1987: 252 e passim), Isabel Allegro de Magalhães encerra o seu percurso, assumidamente perplexo, pelas teorias do feminismo ao longo das sucessivas vagas com a frase: "I flow, but I am rooted, I'm rooted, but I flow" [Fluo, mas tenho raízes, tenho raízes, mas fluo] (p. 123). ${ }^{33}$

Da diferença sexual que o século Xx silenciou em Portugal, antes e depois da Revolução de Abril, trata o artigo de Dee Pryde (2010), "Lésbicas portuguesas no século vinte: apontamentos para a História”. Partindo de um sólido enquadramento transnacional, histórico e teórico, e escrito num tom desafiador não isento de bem justificado sarcasmo, os "apontamentos" de Pryde constituem uma denúncia do tratamento ultrajante que sofreram as lésbicas no nosso país ao longo de todo o século xx, por parte do Estado, da Igreja e da sociedade em geral, e denúncia também da discriminação preconceituosa a que continuam sujeitas ainda hoje entre nós as mulheres-que-amam-mulheres. Como tal, "Lésbicas portuguesas no século vinte" é um documento de luta contra o heteropatriarcado e pelo reconhecimento da identidade lésbica. A verdade é que as lésbicas até (ou sobretudo) por

\footnotetext{
${ }^{31}$ Comparem-se, por exemplo, as ideias de Betty Friedan em The Feminine Mystique (1963) e de Hélène Cixous (2010 [1975]) em Le rire de la Méduse et autres ironies.

${ }^{32}$ Cf. Ramalho Santos (2013: 21-45; 2016: 161-173). Não é este o momento de discutir a suspensão do binarismo sexual proposta pela filósofa e activista Beatriz Preciado (que escolheu mais tarde chamar-se Paul B. Preciado). Cf. Preciado (2002, 2008).

33 Em The Waves (1931), o mais experimental e poético dos seus romances, Virginia Woolf constrói um não-diálogo entre seis personagens, três mulheres e três homens, desde a infância até à velhice ou morte, cujas vozes polifónicas encenam a fluida ambiguidade de identidades e diferenças, subjectividades e sexualidades. Uma dessas personagens diz a certa altura: "I am rooted, but I flow" (Woolf, 2000: 66).
} 
mulheres são muitas vezes oprimidas, como lembra a alusão de Pryde à exclusão das feministas lésbicas da americana National Organization of Women (NOW), cuja presidente na altura, Betty Friedan, as considerou uma "ameaça lilás" (lavender menace). Não tardou que as excluídas desafiadoramente dessem o nome de Lavender Menace à organização por elas imediatamente criada. Não menos desafiadoramente, um grupo de lésbicas portuguesas igualmente rebelde criou, na década de 1990 em Portugal, a revista Lilás, publicação lésbica.

De silenciamento, exclusão, discriminação, exploração, violência - e também de crescente resistência - no mundo da arte nos falam os artigos interligados de Angélica Lima Cruz e Maria José Magalhães. Em "O olhar predador: a arte e a violência do olhar", Cruz (2010) socorre-se de historiadoras e críticas de arte feministas, como Linda Nochlin e Griselda Pollock, para demonstrar como a quase total inexistência de grandes mulheres artistas se deve ao longo domínio tradicionalista e discriminatório do patriarcado sobre os corpos e as mentes das mulheres. Ao mesmo tempo, Cruz recorre a teorias do olhar, como as de John Berger e Laura Mulvey, para denunciar a violência do olhar masculino predador, que perdura tanto na arte como na crítica artística ao longo de todo o século Xx, e proclamar a necessidade de mais e mais consequente crítica de arte feminista. ${ }^{34}$ Não para rasurar o passado, entenda-se, mas para criticamente o contextualizar.

No seguimento do artigo de Angélica Lima Cruz e com ele intimamente articulado, Maria José Magalhães (2010), em "A arte e violência no olhar: activismo feminista e desconstrução da violência contra as mulheres", retoma a questão do olhar hegemónico masculino e sexista que funda a cultura de violência contra as mulheres, que é a nossa (e que só no ano passado reclamou 18 vidas em Portugal). Depois de referir exemplos de obras de arte que denunciam o sexismo e a violência contra as mulheres, Magalhães passa em seguida a explorar algumas das formas artísticas de activismo feminista, em que este tipo de violência é exposto e desconstruído. Analisando intervenções artísticas e instalações realizadas por artistas feministas, como as Guerrilla Girls nos EUA nos anos 1980-1990, Magalhães mostra como o activismo artístico, enquanto crítica feminista do silenciamento, discriminação e violência contra as mulheres, pode desocultar os mecanismos da sua reprodução e dar origem a formas de arte feministas. ${ }^{35} \mathrm{~A}$ arte, articulada

\footnotetext{
${ }^{34}$ Um livro de Angélica Lima Cruz (2009) sobre artes "menores" de mulheres recebe na RCCS 89 uma oportuna recensão crítica de Ana Gabriela Macedo (pp. 207-208). Várias outras muito oportunas recensões críticas feministas enriquecem ainda este número especial sobre "Estudos feministas e cidadania plena" (pp. 207-224).

35 Cf. Confessions of the Guerrilla Girls (1995).
} 
com uma política feminista, defende a autora, é capaz de reinventar novos tipos de olhar, mais atentos à misoginia e ao sexismo discriminatório e violento da cultura que nos tem regido. Exemplar neste sentido é, como mostra Magalhães, a arte de Paula Rego.

A fechar o número especial sobre feminismo, a bela, paradoxal, difícil inteireza de estar na diferença - e também na diferença sexual - explode em "Os teares da memória" da poeta e crítica feminista Ana Luísa Amaral (2010). Musa de si própria, a autora coloca-se, inteira, na mesa de trabalho - mulher, mãe, professora, investigadora, ensaísta, feminista, poeta (esta última palavra, um substantivo comum de dois géneros) - para aí se desmultiplicar em diversas subjectividades credíveis. A prova está nos poemas, nos cerca de 12 livros publicados por Ana Luísa Amaral até 2010. Pois não é a poesia essa linguagem primeira que tudo interroga, que não sossega, que tudo põe em causa - tal como a crítica que esperamos do pensamento feminista? E não se disse já que o poético é feminista?

\section{Feminismo e teatros de guerra}

O número 96 da RCCS, de 2012, "Mulheres e guerras: representações e estratégias", tem por centro a vida de mulheres em cenários de guerra e de pós-guerra, as histórias que sobre elas se contam e, principalmente, as histórias que elas contam.

Da responsabilidade de Tatiana Moura, Júlia Garraio e Sílvia Roque, desde logo as disciplinas de origem das organizadoras garantem um volume transdisciplinar onde se cruzam, e por vezes confluem, metodologias das Humanidades e das Ciências Sociais, num produto final com uma coerência raramente conseguida. Comum a todos os artigos é a questionação dos estereótipos que dizem que as mulheres são da paz e os homens são da guerra, uma matriz que já encontramos nos mitos de Vénus e Marte e que também encontra expressão na Lisístrata de Aristófanes. Neste volume, a reconfiguração de feminilidades e masculinidades é levada ao terreno por excelência da masculinidade hegemónica: o teatro de guerra.

Em "Representaciones, roles y resistências de las mujeres en contextos de violencias", Carmen Megallón Portolés (2012) parte das memórias das histórias ouvidas na infância sobre a Guerra Civil espanhola (1936-1939) para fazer ouvir outras histórias fundadas na experiência de mulheres, prestando atenção à diversidade de posições de ambos os sexos, que questionam, e muitas vezes desmentem mesmo, as representações convencionais. Começando por denunciar o teor androcentrista da disciplina de Relações Internacionais na década de 1990, a autora pretende contribuir para o resgate de vozes antes rasuradas e, desta forma, actuar no sentido de uma 
expansão da própria disciplina que ultrapasse as suas anteriores fronteiras. A heterogeneidade das mulheres encontra-se para além da convencional vítima (real ou potencial): nas "mulheres de armas", guerrilheiras combatendo no terreno em lugares como a Nicarágua, El Salvador ou Guatemala, particularmente na década de 1970. Das convenções, na narrativa que aqui se encontra persiste a ideia dos corpos violáveis das mulheres, com a (possível) excepção do pequeno grupo de "mulheres sagradas", como a mãe ou a enfermeira, em teatros de guerra do século xx tão diversos como o Vietname (décadas de 1960-1970) e a Bósnia (década de 1990). O destaque vai, porém, para as organizações de mulheres que lutam contra a violência, nomeadamente as muitas organizações de mães que procuram filhos desaparecidos, da Argentina à Guatemala, à Rússia, a Cuba ou a El Salvador. A abordagem de Portolés é devedora do trabalho pioneiro nas Relações Internacionais de Cynthia Cockburn (2010), o qual, questionando embora as representações essencialistas que atribuem às mulheres a paz e aos homens a guerra, se centra nas organizações pacifistas de mulheres no que denomina um "feminismo autenticamente transnacional", ${ }^{36}$ que transcende e por vezes combate os discursos nacionalistas. "Disloyal to nation, state and church" [Desleal à nação, ao Estado e à Igreja], como diz Cockburn das mulheres de negro de Belgrado (2010: 143), as solidariedades destas mulheres, fundadas na experiência do sofrimento, contam uma contra-narrativa e colocam novas possibilidades na construção da paz.

Em “'Vamos lá curtir um bocado'. A relação entre identidade sexual, violência e sexualidade em conflitos armados", Gaby Zipfel (2012) aborda uma vertente poucas vezes discutida nos debates sobre a guerra: uma dimensão lúdica e mesmo erótica. Que a participação em combates concebidos como jogo e aventura para jovens rapazes tem esta dimensão é evidente das representações ficcionais da guerra, de forma mais acentuada no cinema; o clássico Apocalypse Now (Francis Ford Coppola, 1979) terá de servir aqui de singular exemplo. Estes jogos têm o efeito de produzir o reforço dos laços entre os machos (male bonding) já presente no discurso heróico da Ilíada ou, para citar um outro clássico, em Henrique $V$ de William Shakespeare, no famoso discurso do Dia de S. Crispim, na véspera da batalha de Azincourt (1415): "We few, we happy few, we band of brothers" [Nós, tão poucos, tão poucos venturosos, nós, bando de irmãos] (1987: IV, 3, 60).

Deste male bonding resulta uma potencialização da violência erotizada que se materializa na violação dos corpos-fêmea, vulneráveis e alvos de um desejo que o não é, que é antes a vontade de triunfo e de humilhar. A guerra

36 "By definition it is transnational" (Cockburn, 2010: 143, itálico no original). 
será talvez o campo que maximiza a assimetria de poder macho/fêmea presente em todas as áreas das práticas sociais. Se a diferença (sexual) se traduz sempre em hierarquia, como suspeita Ramalho Santos (2013), neste artigo Zipfel argumenta que a violência materializa "uma hierarquia da masculinidade e feminilidade" (2012:32). Perante esta equivalência entre a violência sexual e a masculinidade, como ler as mulheres que cometem este tipo de violência? Os escassos casos que entraram para a história, como o caso da soldado norte-americana Lynndie England, em Abu Graib, resultam numa feminização das vítimas masculinas, enquanto as perpetradoras são representadas como monstros contra-natura. A humilhação dos corpos masculinos violados por homens, assunto ainda muito pouco falado e que Zipfel aborda de passagem, é também equiparada a uma feminização. É bem sabido que os corpos das mulheres são simultaneamente campo de batalha e espaço simbólico onde as masculinidades se confrontam, uma representação que é confirmada por esta abordagem panorâmica da violência sexual em teatros de guerra no século Xx.

Da dimensão simbólica do corpo da fêmea como violável e do macho como violador trata o ensaio de Júlia Garraio (2012) em "Hordas de violadores. A instrumentalização da violência sexual em discursos anticomunistas alemães da Guerra Fria”. Trata-se de uma análise das narrativas da violação de mulheres alemãs por soldados do exército soviético no fim da Segunda Guerra Mundial, que resultam na representação da URSS enquanto Outro radical, o bárbaro que nenhuma linguagem poderá civilizar. Esta é uma representação que serviu, à época, à política de integração europeia da República Federal da Alemanha, alimentando e legitimando as posições geopolíticas do Ocidente durante a Guerra Fria. Uma vez mais, estamos perante a instrumentalização dos direitos das mulheres, à semelhança do que mais tarde seria feito aquando da intervenção militar ocidental no Afeganistão, em 2001.37

Em "As memórias das guerras e as guerras das memórias. Mulheres, Moçambique e Timor-Leste”, Teresa Cunha (2012) recolhe narrativas na primeira pessoa de mulheres que experienciaram situações de guerra no que se constitui como uma contra-narrativa da memória. Cunha procura colmatar a ausência destas vozes nas narrativas dominantes de raiz eurocêntrica, numa análise feminista pós-colonial, que de resto está escassamente presente entre os trabalhos sobre que nos temos vindo a debruçar. A autora centra-se no valor político do sofrimento e constata que, se por vezes este resulta no reconhecimento público e na legitimidade para governar,

37 Sobre este assunto, ver Spivak (1988); Abu-Lughod (2002); Bidaseca (2011). 
é muitas vezes uma experiência tida como improdutível e negligenciada. Mais do que tentar mostrar a diversidade dos papéis das mulheres em situações de guerra, a autora procura re-significar o conceito de heroísmo dominante, viril e narcisista. Como diz das mulheres que entrevistou, "elas sabem e dizem-se heroínas" (p. 68). Vale notar que, tendo a casa como frente de combate, a re-significação da valentia que aqui se faz vincula ainda as mulheres à paz.

"Gangues, mulheres e violência sexuada em El Salvador", de Sílvia Roque (2012), problematiza a fronteira entre as representações de mulheres boas/mulheres más a partir de narrativas, entrevistas e histórias de vida de jovens mulheres membros de gangues salvadorenhos. Em situação de pós-guerra a violência manifesta-se em gangues organizados, dos quais fazem parte jovens mulheres cujas motivações, conclui Sílvia Roque, são em tudo semelhantes às dos rapazes: desejo de poder, respeito, diversão, vingança e prazer. Sendo sujeitas aos mesmos rituais de iniciação, e sendo elas próprias perpetradoras de violência, no entanto verifica-se a habitual hierarquia masculino/feminino nas dinâmicas de poder no interior dos gangues. De facto, enquanto a prática da violência faz delas exemplos de "desvios de género", representantes de feminilidades "anormais ou perversas", continuam a ser, também elas, vítimas de um poder sexuado, obrigadas a guardar a "honra" dos seus homens e a manter a respeitabilidade no comportamento sexual, ao mesmo tempo que continuam a ser corpos violáveis, desta vez pelos homens dos gangues rivais.

Iván Darío Ramírez e Grazielle Costa (2012), em "Para além da 'guerra' e da 'paz': territórios de violência em Medellín”, abordam uma situação de pós-guerra, porém em contexto muito diverso. Em Medellín, ao contrário do que acontece em El Salvador, as mulheres estão circunscritas aos tradicionais papéis femininos: passivas, vítimas potenciais, dependendo da protecção dos homens poderosos em troca de favores sexuais; agora em tempos de "paz", tal como fora antes durante a "guerra". Podemos verificar neste estudo mais um exemplo do corpo das mulheres como território do exercício das masculinidades, simultaneamente violáveis e depositárias da "honra" dos homens, uma constante tanto nas guerras nossas contemporâneas como nas narrativas que se conhecem do passado.

Em “'Cidadãos de bem' com armas: representações sexuadas de violência armada, (in)segurança e legítima defesa no Brasil”, Rita Santos (2012) procura questionar os estereótipos das mulheres ligadas à passividade, vulnerabilidade de dependência, no papel de potenciais vítimas, naturalmente pacíficas e pacifistas. A autora faz uma análise sexuada das estratégias retóricas dos materiais de campanha no Referendo sobre a Proibição do 
Comércio de Armas de Fogo e Munições, de 2005. Sem surpresa, verifica-se o recurso à necessidade de protecção das mulheres pelos "homens de bem" como justificação do uso das armas. Trata-se de uma lógica aqui observada ao nível local, mas que não difere muito da usada ao nível da geopolítica global.

\section{Religião e Feminismo}

Em Setembro de 2016, o número 110 da RCCS publicou um dossier sobre religião e cidadania sexual organizado pela teóloga Teresa Martinho Toldy e pela socióloga Ana Cristina Santos, intitulado "Religião, género e cidadania sexual" ${ }^{38}$ A introdução das organizadoras (Toldy e Santos, 2016) contextualiza o tema nos debates mais actuais sobre as relações entre a religião e a sexualidade, mostrando como as três religiões do Livro, jogando com o binómio natural/socialmente construído a favor da manutenção de um rígido statu quo considerado imutável, cerceiam os direitos sexuais não só das mulheres mas de todas as pessoas cuja sexualidade se não conforme com o modelo heterossexual, cissexual, monogâmico e reprodutor. Pessoas LGBTQI, mesmo que crentes e ansiosas por ver conciliadas a religião e a diversidade sexual, são expulsas da comunidade religiosa. As autoras consideram, porém, que nem o secularismo nem a secularização resolvem o problema, dada a crescente relevância da religião nas sociedades contemporâneas.

Esta questão é tratada no artigo de Alberta Giorgi (2016), intitulado "Gender, Religion, and Political Agency: Mapping the Field". Giorgi arma-se de uma vasta bibliografia especializada no âmbito da sociologia, da religião e do feminismo para desconstruir os conceitos correntes de secularismo e secularização, mostrar como os Estudos Feministas contribuem para analisar com rigor tanto a religião como o secularismo, e concluir pela relevância da sociologia da religião para os estudos sociológicos em geral. O objectivo é denunciar o contraste entre a religião, enquanto esfera privada/pessoal, e o secularismo, enquanto esfera pública/política, e reclamar, também no que à religião diz respeito, que o pessoal é político. Às mulheres cabe o privado e o pessoal, mas, no momento em que as mulheres reclamam a posse plena do seu corpo, logo o corpo da mulher passa a ser público e político, como têm mostrado as lutas pelo aborto.

O binómio público/privado tem alguma correspondência com o binómio natural/socialmente construído. Em "Fighting about (Sexual) Citizenship:

${ }_{38}$ O dossier está em parte relacionado com o projecto INTIMATE, liderado por Ana Cristina Santos, financiado pelo Conselho Europeu de Investigação (ERC) e sediado no CES. 
Italy's 'Nature or Culture' Dilemma”, as sociólogas italianas Elisa Bellè, Caterina Peroni e Elisa Rapetti (2016), servindo-se do método de análise do discurso proposto por Norman Fairclough, discutem recentes confrontos em Itália sobre a conquista da cidadania sexual, de que a Igreja Católica e as forças mais conservadoras querem excluir os grupos LGBTQI. Para os conservadores, a natureza define o que é aceitável - família, entendida como casamento heterossexual monogâmico, e filhos; por isso se sentem ameaçados por qualquer projecto de educação sexual nas escolas que possa iniciar as crianças em opções identitárias não "naturais", como as patenteadas pelos grupos LGBTQI. O "dilema”, a que alude o título do artigo, consiste em que tanto as forças conservadoras como os grupos LGBTQI invocam a "natureza" nos seus discursos: para os conservadores, a ordem natural define o masculino, o feminino, a monogamia e a heterossexualidade; os grupos LGBTQI, por sua vez, defendem o reconhecimento de todas as diferenças como um imperativo, dado que as diferenças decorrem da condição "natural" de todos os seres humanos. Em face disto, as autoras do artigo temem que os Estudos Feministas sobre as diferentes identidades, orientações e performatividades sexuais passem a ser dispensáveis.

"Pastores, ovelhas desgarradas e as disputas pelo rebanho: sobre a transcrucificação na Parada do orgulho LGBT de São Paulo em 2015”, assinado por Rodrigo Otávio Moretti-Pires, Zeno Carlos Tesser Júnior, Marcelo Vieira e Murilo dos Santos Moscheta (2016), quatro cientistas sociais ligados à saúde pública e à sociologia política, discute o mesmo tema no contexto de um Brasil cada vez mais intolerante das diferenças sexuais identitárias em virtude da influência crescente dos cristãos evangélicos, que têm vindo paulatinamente a transformar a religião em política de exclusão. O objectivo dos autores, com base em Judith Butler (performatividade) e Pierre Bourdieu (babitus, campo político), é denunciar o pensamento religioso retrógrada, teimosamente amarrado aos velhos binómios masculino/feminino e natural/socialmente construído e à heteronormatividade compulsória, e cuja intolerância violenta o leva a ignorar, não só as transformações sociais do nosso tempo, mas também a ciência que delas dá conta. A figura da transcrucificação referida no título é a imagem perfeita da violência dirigida por pastores e políticos evangélicos às pessoas LGBT, ou seja, a todos aqueles considerados a-sociais e por isso a excluir da protecção do Estado.

De novo ao Brasil nos leva o ensaio da antropóloga Daniela Cordovil (2016), "Espiritualidades feministas: relações de gênero e padrões de família entre adeptos da wicca e do candomblé no Brasil". Informada pelo trabalho de Cynthia Eller (2000) sobre o mito do matriarcado pré-histórico, Cordovil escreve sobre duas religiões e espiritualidades, o candomblé (de inspiração 
africana) e a wicca (de recente origem neo-pagã), que atribuem às mulheres grande autoridade e poder, tanto na religião como na comunidade em geral. São também religiões de grande tolerância para com padrões familiares diversos e para com as diferentes identidades e orientações sexuais. Como tal, o candomblé e a wicca impõem-se no Brasil como forte resistência ao cristianismo reaccionário dos evangélicos, pelo simples facto de demonstrarem que é possível crer e viver de modos diferentes, sem, por exemplo, controlar o corpo das mulheres e sem lhes cercear os direitos reprodutivos.

O que nos leva à questão do aborto. A interrupção voluntária da gravidez foi despenalizada em Portugal em 2007, após um longo período de controvérsia e dois referendos, o primeiro dos quais resultou no "não" (1998) e o segundo (2007), no "sim". No seu número 13 (Fevereiro 1984), a RCCS deu espaço ao debate sobre a despenalização do aborto que na década de 1980 agitou Portugal. Dois breves textos, um de Graça Abranches (1984b) - "Ditos, não-ditos e mito" - e outro de Virgínia Ferreira (1984) - “(Des)penalizar o aborto ou (des)penalizar um certo sexo" -, reflectem com base na realidade da sociedade portuguesa, em que todos os dias tantas mulheres abortavam clandestinamente e em péssimas condições, e com base em investigação incidindo sobre a análise de conteúdo da imprensa portuguesa relativo ao debate. Ambos os textos assumem desassombradamente o pensamento feminista materialista contra a redistribuição desigual. Afinal, o pessoal-é-político-e-económico. Ao mesmo tempo que denunciam as contradições e a hipocrisia dos "defensores" da "vida" e da "família" - a começar pela Igreja Católica - que utilizam o debate para fazer avançar as suas agendas conservadoras, Abranches e Ferreira reivindicam para as mulheres a posse plena do seu corpo. Sem isso, não haverá nunca para as mulheres plena cidadania, a qual, deixam elas transpirar, estava na altura sempre ausente da mesa de discussão sobre o aborto. Por detrás da argumentação em ambos os textos, estas leitoras julgam escutar as críticas - de Marx, Engels, Freud, Beauvoir - ao pensamento hegemónico sobre a diferença sexual e a família, porventura revisto pela psicanálise feminista de Juliet Mitchell (1974) e pelo feminismo radical de Shulamith Firestone (1970). ${ }^{39}$

\section{Conclusão}

A RCCS tem dado nas suas páginas amplo espaço às problemáticas feministas em várias áreas e nas suas diferentes vertentes. Decerto que continuará a dar. Resta saber se, doravante, a investigação que se reivindica do feminismo

39 Dois anos mais tarde, Graça Abranches e Virgínia Ferreira deram a lume um muito bem informado artigo sobre o mesmo tema. Ver Abranches e Ferreira (1986: 477-492). 
continuará a ter em conta mulheres em luta pela sua ainda tão distante plena cidadania, ou se se sentirá confortável com o chamado pós-feminismo, que considera obsoletas as lutas das mulheres pelos seus direitos, ou como lidará com o recente conceito de xenofeminismo, que projecta uma utopia feminista eliminando a diferença sexual e que, em última análise, se arrisca a encontrar-se sem mulheres - e sem homens (Hester, 2018). ${ }^{40}$ No início do século Xx, o poeta modernista português Mário de Sá-Carneiro, lamentando em carta a Fernando Pessoa (31.12.1912) a triste existência de apenas dois sexos, cria a orgia libertária da proliferação de sexos múltiplos no conto, "O homem dos sonhos". Para os poetas modernistas portugueses, essa geração "superior" por estar isenta de complicações sentimentais (leia-se "de mulheres”), as mulheres, esse deficitário sexo-que-não-é, eram claramente descartáveis. ${ }^{41}$ E hoje?

Revisto por Rita Cabral

\section{Referências bibliográficas}

Abranches, Graça (1980), "Re-lendo A Room of One's Own. Onde se conta de mudas que ouvem, surdos que falam e mudas que aprenderam a falar", Revista Crítica de Ciências Sociais, 4/5, 129-156.

Abranches, Graça (1981), "Sheila Rowbotham, Lynne Segal e Hilary Wainwright, Beyond the Fragments. Feminism and the Making of Socialism, Londres, Merlin, Press, 1980/1979", Revista Crítica de Ciências Sociais, 6, 207-212.

Abranches, Graça (1984a), "Um passeio doméstico: à procura da utopia num espaço cor-de-rosa", Revista Crítica de Ciências Sociais, 13, 35-44.

Abranches, Graça (1984b), "Ditos, não-ditos e mito", Revista Crítica de Ciências Sociais, 13, 101-105.

Abranches, Graça (1996), “'Teacher, women can be nouns, too!'. A igualdade de oportunidades na formação inicial de docentes de Inglês”, Revista Crítica de Ciências Sociais, 45, 185-198.

Abranches, Graça (1998), "'On What Terms Shall We Join the Procession of Educated Men?' Teaching Feminist Studies at the University of Coimbra”, Oficina do CES, 125. Acessível em https://ces.uc.pt/publicacoes/oficina/ficheiros/125.pdf.

\footnotetext{
${ }_{40}$ Registe-se, no entanto, o contributo de Hester para a revitalização da luta da segunda vaga contra o poder masculinista da medicina e para a recuperação dos cuidados de saúde e ajuda mútua então praticados em comunidades de mulheres, conforme proposta de Our Bodies Ourselves (2011), publicado pela primeira vez em 1971.

${ }^{41}$ Cf. Ramalho Santos (2003: cap. V - "Intersexualities and the Modernist Ode. The Sea Poems of Pessoa and Crane"; 2017: 44-65).
} 
Abranches, Graça; Ferreira, Virgínia (1986), "O debate sobre o aborto e a ortopedia discursiva da sexualidade”, Análise Social, XXII(3. -4. ${ }^{\circ}$ ), 92-93, 477-492.

Abu-Lughod, Lila (2002), "Do Muslim Women Really Need Saving? Anthropological Reflections on Cultural Relativism and Its Others", American Anthropologist, 104(3), 783-790.

Ackers, Louise (1998), “'Cuidar de longe’: mulheres, mobilidade e autonomia na União Europeia”, Revista Crítica de Ciências Sociais, 50, 121-151.

Almeida, Miguel Vale de (2006), "O casamento entre pessoas do mesmo sexo. Sobre 'gentes remotas e estranhas' numa 'sociedade decente'”, Revista Crítica de Ciências Sociais, 76, 17-31.

Amâncio, Lígia (1992), "Assimetrias nas representações do género”, Revista Crítica de Ciências Sociais, 34, 9-22.

Amâncio, Lígia (2003), "O género no discurso das ciências sociais", Análise Social, XXXVIII(168), 687-714.

Amaral, Ana Luísa (2010), “Os teares da memória”, Revista Crítica de Ciências Sociais, 89, 185-205.

André, Carlo Ascenso (2010), "A ironia ovidiana na subversão do protocolo amoroso em Roma”, Revista Crítica de Ciências Sociais, 89, 41-54.

Beauvoir, Simone (1949), Le deuxième sexe. Paris: Gallimard.

Bebiano, Adriana (1994), "As castas e as outras: uma leitura das heroínas de Shakespeare", Adágio - Revista do Centro Dramático de Évora, 14 (Julho/Setembro), 24-27.

Bebiano, Adriana (2009), "Da vida das mulheres infames. A história segundo Emma Donoghue”, Anglo-Saxonica, II(27), 21-36.

Bebiano, Adriana (2017), "Meninas, senhoras e galdérias: representações das mulheres em língua portuguesa”, in Isabel Caldeira; Graça Capinha; Jacinta Matos (orgs.), The Edge of One of Many Circles: Homenagem a Irene Ramalho Santos. Coimbra: Imprensa da Universidade de Coimbra, 11-25.

Bellè, Elisa; Peroni, Caterina; Rapetti, Elisa (2016), "Fighting about (Sexual) Citizenship: Italy's 'Nature or Culture' Dilemma”, Revista Crítica de Ciências Sociais, 111, 73-98.

Bidaseca, Karina (2011), "Mujeres blancas buscando salvar las mujeres color café de los hombres color café: desigualdad, colonialismo jurídico y feminismo poscolonial”, Andiamos. Revista de Investigácion Social, 8(17), 61-89.

Blay, Eva Alterman; Ramos, Rosana da Conceição (1992), "Mulher, ciência e sociedade: abordagem das relações de género nas disciplinas da Universidade de São Paulo", Revista Crítica de Ciências Sociais, 34, 23-38.

Braidotti, Rosi (1998), "A diferença sexual e o controverso conceito de cidadania europeia”, Revista Crítica de Ciências Sociais, 50, 73-82.

Braidotti, Rosi (2000), “Teratologies”, in Ian Buchanan; Claire Colebrook (orgs.), Deleuze and Feminist Theory. Edinburgh: Edinburgh University Press, 56-172. 
Braidotti, Rosi (2001), "Becoming Woman: Rethinking the Positivity of Difference”, in Elisabeth Bronfen; Misha Kavka (orgs.), Feminist Consequences. Theory for the New Century. New York: Columbia University Press, 381-413.

Braidotti, Rosi; Butler, Judith (1994), "Feminism by Any Other Name", Differences: A Journal of Feminist Cultural Studies, 6(2/3), 27-61. Acessível em https://bagelabyss.files. wordpress.com/2012/02/butler-and-braidotti-interview-feminism-by-any-other-name1.pdf.

Brown, Wendy (2005), Edgework. Critical Essays on Knowledge and Politics. Princeton/ /Oxford: Princeton University Press.

Buikema, Rosemarie (2010), "O conteúdo da forma e outras políticas textuais. Configurações de nação e cidadania em Disgrace e Agaat", Revista Crítica de Ciências Sociais, 89, 55-69.

Butler, Judith (1990), Gender Trouble. Feminism and the Subversion of Identity. New York: Routledge.

Butler, Judith (1997), "Merely Cultural”, Social Text-Queer Transexions of Race, Nation, and Gender, 52/53(Autumn-Winter), 265-267.

Butler, Judith (2000), Antigone's Claim: Kinship between Life and Death. New York: Columbia University Press.

Butler, Judith (2004), Undoing Gender. New York: Routledge.

Carneiro, Nuno Santos; Menezes, Isabel (2006), “'Do anel à aliança’: sentido dos iguais e emancipação pessoal na psicologia das sexualidades”, Revista Crítica de Ciências Sociais, 76, 73-89.

Cascais, António Fernando (org.) (2004), Indisciplinar a teoria. Estudos gays, lésbicos e queer. Lisboa: Fenda.

Cascais, Fernando (2006), "Diferentes como só nós. O associativismo GLBT português em três andamentos”, Revista Crítica de Ciências Sociais, 76, 109-126.

Cavarero, Adriana (1990), Nonostante Platone. Figure femminile nella filosofia antica. Roma: Editori Reuniti.

Cavarero, Adriana (1995a), Corpo in figure. Filosofia e politica della corporeità. Milano: Feltrinelli.

Cavarero, Adriana (1995b), In Spite of Plato: A Feminist Rewriting of Ancient Philosophy. Foreword by Rosi Braidotti. New York: Routledge. Tradução de Serena Anderlini-D’Onofrio e Áine O'Healy.

Cavarero, Adriana (2002), Stately Bodies: Literature, Philosophy and the Question of Gender. Ann Arbor: University of Michigan Press. Tradução de Robert de Lucca e Deana Shemek.

Cixous, Hélène (2010), Le rire de la Méduse et autres ironies. Paris: Galilée [orig. 1975].

Cockburn, Cynthia (2010), "Gender Relations as Causal in Militarization and War", International Feminist Journal of Politics, 12(2), 139-157.

Coelho, Lina (2016), "Finanças conjugais, desigualdades de género e bem-estar: facetas de um Portugal em crise”, Revista Crítica de Ciências Sociais, 111, 59-80. 
Coetzee, J. M. (1999), Disgrace. London: Secker \& Warburg.

Collins, Marie M.; Sylvie Weil-Sayre (1972), "Flora Trista: Forgotten Feminist and Socialist”, Nineteenth-Century French Studies, 1(4), 229-234.

Confessions of the Guerrilla Girls by the Guerrilla Girls (Whoever They Really Are) (1995), New York: Harper Perennial.

Cordovil, Daniela (2016), "Espiritualidades feministas: relações de gênero e padrões de família entre adeptos da wicca e do candomblé no Brasil", Revista Crítica de Ciências Sociais, 111, 117-140.

Crenshaw, Kimberlé (1989), "Demarginalizing the Intersection of Race and Sex: A Black Feminist Critique of Antidiscrimination Doctrine, Feminist Theory and Antiracist Politics", University of Chicago Legal Forum, 140 [Special issue "Feminism in the Law: Theory, Practice and Criticism”], 139-168.

Crowther, Prudence (2018), "Zeus: The Apology”, The New York Review of Books, 65(1).

Cruz, Angélica Lima (2010), "O olhar predador: a arte e a violência do olhar”, Revista Crítica de Ciências Sociais, 89, 71-87.

Cruzeiro, Maria Manuela (2004), “As mulheres e a Guerra Colonial: Um silêncio demasiado ruidoso", Revista Crítica de Ciências Sociais, 68, 31-42.

Cunha, Teresa (2010), "Imobilidades e fracturas: mulheres, identidades e narrativas viajantes em Timor-Leste”, Revista Crítica de Ciências Sociais, 89, 141-152.

Cunha, Teresa (2012), "As memórias das guerras e as guerras das memórias. Mulheres, Moçambique e Timor-Leste”, Revista Crítica de Ciências Sociais, 96, 67-86.

Dee Pryde (2010), "Lésbicas portuguesas no século vinte: apontamentos para a História", Revista Crítica de Ciências Sociais, 89, 127-139.

Deleuze, Gilles; Guattari, Felix (1987), A Thousand Plateaus, Capitalism and Schizopbrenia. Minneapolis/London: University of Minnesota Press. Tradução e prefácio de Brian Massumi.

duBois, Page (2015), Sappho. London: I. B. Tauris.

Eller, Cynthia (2000), The Myth of Matriarchal Prebistory. Why and Invented Past Won't Give Women a Future. Boston: Beacon Press.

Faria, Isabel Hub; Grosso, Maria José; Lopes, Rosa (1986), "Dez anos de auto-referência: Que transformação na orientação para o significado de mulher na Assembleia da República?”, Revista Crítica de Ciências Sociais, 18/19/20, 213-224.

Ferreira, Virgínia (1981), "Mulheres, família e trabalho doméstico no capitalismo", Revista Crítica de Ciências Sociais, 6, 47-86.

Ferreira, Virgínia (1984), “(Des)penalizar o aborto ou (des)penalizar um certo sexo”, Revista Crítica de Ciências Sociais, 13, 106-110.

Ferreira, Virgínia (1988), “O feminismo na pós-modernidade”, Revista Crítica de Ciências Sociais, 24, 93-106.

Ferreira, Virgínia (1992), "Informatização e feminização dos escritórios em Portugal”, Revista Crítica de Ciências Sociais, 34, 213-241. 
Ferreira, Virgínia (1998/1999), “Os paradoxos da situação das mulheres em Portugal”, Revista Crítica de Ciências Sociais, 52/53, 199-227.

Fiorenza, Elisabeth Schüssler (1998), Sharing Her Word. Feminist Biblical Interpretation in Context. Boston: Beacon Press.

Firestone, Shulamith (1970), The Dialectics of Sex. The Case for Feminist Revolution. New York: Morrow.

Fraser, Nancy (1997a), "From Redistribution to Recognition? Dilemmas of Justice in a 'Postsocialist' Age", Justice Interruptus. Critical Reflection on the "Postsocialist" Condition. New York/London: Routledge, 11-39.

Fraser, Nancy (1997b), "Heterosexism, Misrecognition, and Capitalism: A Response to Judith Butler", Social Text, 52/53, 279-289.

Fraser, Nancy (2003), "Social Justice in the Age of Identity Politics: Redistribution, Recognition, and Participation", in Nancy Fraser; Axel Honneth, Redistribution or Recognition? A Political-Philosophical Exchange. London/New York: Verso, 7-109.

Fraser, Nancy (2013), "How Feminism Became Capitalism's Handmaiden - And How to Reclaim It”, The Guardian, de 14 de Outubro. Consultado a 20.01.2016, em https://www. theguardian.com/commentisfree/2013/oct/14/feminism-capitalist-handmaidenneoliberal.

Friedan, Betty (1963), The Feminine Mystique. New York: Norton.

Gálvez, Lina; Rodríguez-Modroño, Paula (2016), “A Gender Analysis of the Great Recession and 'Austericide' in Spain”, Revista Crítica de Ciências Sociais, 111, 133-152.

Garraio, Júlia (2012), "Hordas de violadores. A instrumentalização da violência sexual em discursos anticomunistas alemães da Guerra Fria”, Revista Crítica de Ciências Sociais, 96, 47-66.

Gaspard, Françoise (1998), "Invisíveis, diabolizadas, instrumentalizadas: figuras de mulheres migrantes e suas filhas na Europa”, Revista Crítica de Ciências Sociais, 50, 83-101.

Gerard, Jane F. (2013), The Dinner Party. Judy Chicago and the Power of Popular Feminism, 1970-2007. Athens: The University of Georgia Press.

Giorgi, Alberta (2016), "Gender, Religion, and Political Agency: Mapping the Field”, Revista Crítica de Ciências Sociais, 110, 51-72.

Grosz, Elizabeth (1994), Volatile Bodies. Toward a Corporeal Feminism. Bloomington/ /Indianapolis: Indiana University Press.

Grosz, Elizabeth (2017), The Incorporeal: Ontology, Ethics, and the Limits of Materialism. New York: Columbia University Press.

Haraway, Donna J. (1991), “A Cyborg Manifesto: Science, Technology, and Socialist-Feminism in the Late Twentieth Century”, Simians, Cyborgs and Women: The Reinvention of Nature. London: Free Association Books, 149-182.

Harding, Sandra (1991), Whose Science, Whose Knowledge? Ithaca, NY: Cornell University Press. 
Harding, Sandra (org.) (2004), The Feminist Standpoint Theory Reader. Intellectual and Political Controversies. New York/London: Routledge.

Henriques, Fernanda (2010), "Concepções filosóficas e representações do feminino: subsídios para uma hermenêutica crítica da tradição filosófica”, Revista Crítica de Ciências Sociais, 89, 11-28.

Henriques, Fernanda (2016), Filosofia e género. Outras narrativas da tradição ocidental. Lisboa: Edições Colibri.

Hester, Helen (2018), Xenofeminism. London: Polity.

Joaquim, Teresa (1997), Menina e moça. A construção social da feminilidade. Séculos XVII-XIX. Lisboa: Fim de Século.

Jorge, Lídia (1988), A costa dos murmúrios. Lisboa: Dom Quixote.

Keating, Clara (1994), “A construção da polémica da begemonia e da diferença nos estudos sobre linguagem e diferença sexual (a propósito de You Just Don't Understand, de Deborah Tannen)", Revista Crítica de Ciências Sociais, 40, 173-190.

Kirchler, Erich; Winter, Laura; Penz, Elfriede (2016), "Methods of Studying Economic Decisions in Private Households", Revista Crítica de Ciências Sociais, 111, 81-108.

Layoun, Mary N. (1998), "A nação em transculturação e os espaços sexualmente diferenciados da diáspora: Mulher/Homem e cidadania”, Revista Crítica de Ciências Sociais, 50, 27-46.

Lisboa, Maria Manuel (2004), “'Até ao fim do mundo': Amor, rancor e guerra em Hélia Correia”, Revista Crítica de Ciências Sociais, 68, 65-83.

Liska, Vivian (2000), "Die Moderne - ein Weib". Am Beispiel von Romanen Ricarda Huchs and Annette Kolbs. Tübingen: Francke.

Liska, Vivian (2006), "Para que tenha significado e para que tenha importância: um modernismo para o século XxI", Revista Crítica de Ciências Sociais, 74, 9-27.

Lopes, Ana Cristina Macário (1979), "Jean-Claude Milner, L'amour de la langue, Paris, Seuil, 1978”, Revista Crítica de Ciências Sociais, 3, 120-124.

Magalhães, Maria José (2010), "A arte e violência no olhar: activismo feminista e desconstrução da violência contra as mulheres”, Revista Crítica de Ciências Sociais, 89, 89-109.

Magalhães, Isabel Allegro de (2010), "A instância corpórea do humano: sexualidades e subjectividades, mulheres e ética”, Revista Crítica de Ciências Sociais, 89, 111-125.

Maluf, Sônia Weidner (1992), "Bruxas e bruxaria na Lagoa da Conceição: um estudo sobre as representações de poder feminino na Ilha de Santa Catarina”, Revista Crítica de Ciências Sociais, 34, 99-112.

Medeiros, Ana de (2004), "Re-escrevendo a História: A costa dos murmúrios de Lídia Jorge e L'Amour, la fantasia de Assia Djebar”, Revista Crítica de Ciências Sociais, 68, 101-115.

Mesquita, Paula (2006a), "Vestidos para matar: o sexo das guerras em Cather e Faulkner”, Revista Crítica de Ciências Sociais, 74, 75-83. 
Mesquita, Paula (2006b), O que Billy quer vestir. Dinâmicas sociossexuais em Willa Cather e William Faulkner. Porto: Campo das Letras.

Millett, Kate (1970), Sexual Politics. Garden City: Doubleday.

Mitchell, Juliet (1974), Psychoanalysis and Feminism: Freud, Reich, Laing, and Women. New York: Pantheon Books.

Moita, Gabriela (2001), Discurso sobre a homossexualidade no contexto clínico: a bomossexualidade de dois lados do espelho. Porto: Edição de autor.

Moita, Gabriela (2006), "A patologia da diversidade sexual: a homofobia no discurso de clínicos”, Revista Crítica de Ciências Sociais, 76, 53-72.

Molina, María León (2016), "Miriano, Costanza (2013), Cásate y sé sumisa: experiencia radical para mujeres sin miedo”, Revista Crítica de Ciências Sociais, 111, 160-162.

Monteiro, Rosa (2011), "A política de quotas em Portugal: o papel dos partidos políticos e o feminismo de Estado”, Revista Crítica de Ciências Sociais, 92, 31-50.

Moretti-Pires, Rodrigo Otávio; Tesser Júnior, Zeno Carlos; Vieira, Marcelo; Moscheta, Murilo dos Santos (2016), "Pastores, ovelhas desgarradas e as disputas pelo rebanho: sobre a transcrucificação na Parada do orgulho LGBT de São Paulo em 2015”, Revista Crítica de Ciências Sociais, 111, 99-116.

Neves, Helena (2004), "Amor em tempo de guerra: Guerra Colonial, a (in)comunicabilidade (im)possível”, Revista Crítica de Ciências Sociais, 68, 43-63.

Niekerk, Marlene van (2006), Agaat. Amsterdam: Querido.

Oliveira, Miguel (2016), "Eswaran, Mukesh (2014), Why Gender Matters in Economics”, Revista Crítica de Ciências Sociais, 111, 153-155.

O’Rourke, Michael (2006), "Que há de tão queer na teoria queer por-vir?”, Revista Crítica de Ciências Sociais, 76, 127-140.

Our Bodies Ourselves (2011) (Boston Women's Health Book Collective). New York: Simon \& Schuster.

Padilha, Laura (2004), "Dois olhares e uma guerra”, Revista Crítica de Ciências Sociais, 68, 117-128.

Pateman, Carole (2010), "Garantir a cidadania das mulheres: a indiferença e outros obstáculos”, Revista Crítica de Ciências Sociais, 89, 29-40.

Perista, Heloísa (1998), "Mulheres em diáspora na União Europeia: percursos migratórios e trajectórias profissionais e familiares”, Revista Crítica de Ciências Sociais, 50, 153-165.

Pintasilgo, Maria de Lourdes (1998), "As mulheres, a cidadania e a sociedade activa”, Revista Crítica de Ciências Sociais, 50, 15-26.

Pires, Maria do Céu (2017), "Filosofia e género. Outras narrativas sobre a tradição ocidental, de Fernanda Henriques. Lisboa: Edições Colibri, 2016, 256 pp.”, ex aequo, Revista da Associação Portuguesa de Estudos sobre as Mulberes, 36, 226-230.

Piselli, Fortunata (1998), "Mulheres migrantes: uma abordagem a partir da teoria das redes”, Revista Crítica de Ciências Sociais, 50, 103-119. 
Poeschl, Gabrielle (2016), "Relação de poder entre cônjuges e representações sociais das estratégias de influência no casal”, Revista Crítica de Ciências Sociais, 111, 109-132. Portolés, Carmen Megallón (2012), "Representaciones, roles y resistencias, de las mujeres en contextos de violencias", Revista Crítica de Ciências Sociais, 96, 9-30.

Preciado, Beatriz (2002), Manifesto contra-sexual. Prácticas subversivas de identidade sexual. Madrid: Opera Prima.

Preciado, Beatriz (2008), Testo Yonqui. Madrid: Espasa.

Ramalho, Maria Irene (2001a), "Os Estudos sobre as Mulheres e o saber. Onde se conclui que o poético é feminista”, ex aequo. Revista da Associação Portuguesa de Estudos sobre as Mulheres, 5, 107-122.

Ramalho, Maria Irene (2001b), "A sogra de Rute ou intersexualidades”, in Boaventura de Sousa Santos (org.), Globalização. Fatalidade ou utopia? Porto: Edições Afrontamento, 525-555.

Ramalho, Maria Irene (2016), “Diferença? Ou variedade infinita?”, Cadernos de Literatura Comparada, 35, 161-173.

Ramalho Santos, Irene (2003), Atlantic Poets. Fernando Pessoa's Turn in Anglo-American Modernism. Hanover/London: University Press of New England.

Ramalho Santos, Irene (2013), "Difference and Hierarchy Revisited by Feminism”, Anglo Saxonica, III(6), 23-45.

Ramalho Santos, M. Irene (2017), "Orpheu et al. Modernism, Women, and the War", Pessoa Plural. A Journal of Fernando Pessoa Studies, 11, 44-65.

Ramírez, Iván Darío; Costa, Grazielle (2012), “Para além da 'guerra' e da 'paz': territórios de violência em Medellín”, Revista Crítica de Ciências Sociais, 96, 117-132.

Ramos, Wanda (1981), Percursos (do Luachimo ao Luena). Lisboa: Presença.

Regulska, Joanna (1998), “A nova 'outra' mulher europeia”, Revista Crítica de Ciências Sociais, 50, 47-71.

Ribeiro, Manuela (1998), "Tomando a dianteira: mulheres e emigração em regiões desfavorecidas”, Revista Crítica de Ciências Sociais, 50, 167-182.

Ribeiro, Margarida Calafate (2004), "África no feminino: As mulheres portuguesas e a Guerra Colonial”, Revista Crítica de Ciências Sociais, 68, 7-30.

Ribeiro, Margarida Calafate (2007), África no feminino. As mulheres portuguesas e a Guerra Colonial. Porto: Edições Afrontamento.

Roque, Sílvia (2012), "Gangues, mulheres e violência sexuada em El Salvador”, Revista Crítica de Ciências Sociais, 96, 87-116.

Roseneil, Sasha (2006), "Viver e amar para além da heteronorma: uma análise queer das relações pessoais no século xxI”, Revista Crítica de Ciências Sociais, 76, 33-51.

Rowbotham, Sheila (1973), Women's Consciousness, Man's World. Harmondsworth: Penguin. Santo, Alda Espírito (1978), É nosso o solo sagrado da terra. Lisboa: Ulmeiro.

Santos, Ana Cristina (2006a), "Estudos queer: Identidades, contextos e acção colectiva", Revista Crítica de Ciências Sociais, 76, 3-15. 
Santos, Ana Cristina (2006b), "Entre a academia e o activismo: sociologia, estudos queer e movimento LGBT em Portugal”, Revista Crítica de Ciências Sociais, 76, 91-108. Santos, Ana Lúcia (2013), "Para lá do binarismo? O intersexo como desafio epistemológico e político", Revista Crítica de Ciências Sociais, 102, 3-20.

Santos, Boaventura de Sousa (1997), "Por uma concepção multicultural de direitos humanos", Revista Crítica de Ciências Sociais, 48, 11-32.

Santos, Cecília MacDowell (2010), "Da delegacia da mulher à Lei Maria da Penha: Absorção/tradução de demandas feministas pelo Estado”, Revista Crítica de Ciências Sociais, 89, 153-170.

Santos, Rita (2012), “'Cidadãos de bem’ com armas: representações sexuadas de violência armada, (in)segurança e legítima defesa no Brasil”, Revista Crítica de Ciências Sociais, 96, 133-164.

Scott, Joan W. (1986), “Gender: A Useful Category of Historical Analysis”, The American Historical Review, 91(5), 1053-1075. Acessível em http://www.jstor.org/ stable/1864376.

Shakespeare, William (1987), King Henry V. The Arden Shakespeare, J. H. Walyter (org.), London/New York: Methuen.

Spillers, Hortense (1984), "Interstices. A Small Drama of Words”, Pleasure \& Danger. Exploring Female Sexuality. Boston/London: Routledge \& Kegan Paul.

Spivak, Gayatri (1988), “Can the Subaltern Speak?”, in Cary Nelson; Lawrence Grossberg (orgs.), Marxism and the Interpretation of Culture. Urbana/Chicago: University of Illinois Press, 271-313 [orig. 1983].

Tannen, Deborah (1990), You Just Don't Understand. Women and Men in Conversation. New York: Morrow.

Toldy, Teresa Martinho (2010a), "A violência e o poder da(s) palavra(s): a religião cristã e as mulheres", Revista Crítica de Ciências Sociais, 89, 171-183.

Toldy, Teresa Martinho (2010b), “'Sonhos secularistas' e 'direitos de mulheres'. Notas acerca de uma 'relação ambígua'”, Revista Crítica de Ciências Sociais, 90, 5-24.

Toldy, Teresa Martinho; Santos, Ana Cristina (2016), "Religião, género e cidadania sexual: uma introdução", Revista Crítica de Ciências Sociais, 111, 43-50.

Tristán, Flora (1843), Union ouvrière. Paris: Édition Populaire. Consultado a 17.02.208 em http://gallica.bnf.fr/ark:/12148/btv1b8626625v/f11.image.

Tristán, Flora (2007), The Workers Union. Tradução de Beverly Livingston. Chicago: University of Illinois Press.

Tubert, Silvia (1996), Mulheres sem sombra. Maternidade e novas tecnologias de reprodução. Rio de Janeiro: Rosa dos Tempos. Tradução de Graciela Rodriguez [orig. 1991].

Vecchi, Roberto (2004), "Incoincidências de autoras: Fragmentos de um discurso não só amoroso na literatura da Guerra Colonial”, Revista Crítica de Ciências Sociais, 68, 85-100.

Wollstonecraft, Mary (2014), A Vindication of the Rights of Woman. Organização de Eileen Hunt Botting. New Haven/London: Yale University Press [orig. 1792]. 
Woolf, Virginia (2000), The Waves. New York: Vintage.

Zipfel, Gaby (2012), “'Vamos lá curtir um bocado’. A relação entre identidade sexual, violência e sexualidade em conflitos armados", Revista Crítica de Ciências Sociais, $96,31-46$.

\section{Adriana Bebiano}

Centro de Estudos Sociais da Universidade de Coimbra | Faculdade de Letras da Universidade de Coimbra

Colégio de S. Jerónimo, Largo D. Dinis, Apartado 3087, 3000-995 Coimbra, Portugal

Contacto: adrianabebiano@gmail.com

\section{Maria Irene Ramalho}

Centro de Estudos Sociais da Universidade de Coimbra | Faculdade de Letras da Universidade de Coimbra I University of Wisconsin-Madison

Colégio de S. Jerónimo, Largo D. Dinis, Apartado 3087, 3000-995 Coimbra, Portugal

Contacto: irsantos@wisc.edu

\section{Revista Crítica de Ciências Sociais and Feminism (1978-2017)}

The aim of this article is to reflect critically on work pertaining to feminist topics published in the Revista Critica de Ciências Sociais (RCCS) since its foundation in 1978 to the present day. Such a critical outlook, in articulation with the emergent feminist theories from recent decades, will no doubt produce a renewed self-image for the RCCS as well as the Centre for Social Studies of the University of Coimbra, the institution responsible for editing the journal.

Keywords: citizenship; critical epistemology; feminism; Revista Crítica de Ciências Sociais.

\section{La Revista Crítica de Ciências Sociais et le féminisme (1978-2017)}

L'objectif de cet article est de mener une refléxion critique sur les travaux publiés dans la Revista Crítica de Ciências Sociais (RCCS), de sa fondation à nos jours. Plus concrètement, sur ceux ayant trait à la thématique féministe. Ce regard critique, en articulation avec les théories féministes émergentes de ces dernières décennies, ne manquera pas d'engendrer une image rénovée que la RCCS peut avoir d'elle-même, tout autant que le Centre d'Études Sociales de l'Université de Coimbra, l'institution responsable de l'édition de la revue.

Mots-clés: citoyenneté; épistémologie critique; féminisme; Revista Crítica de Ciências Sociais. 
